
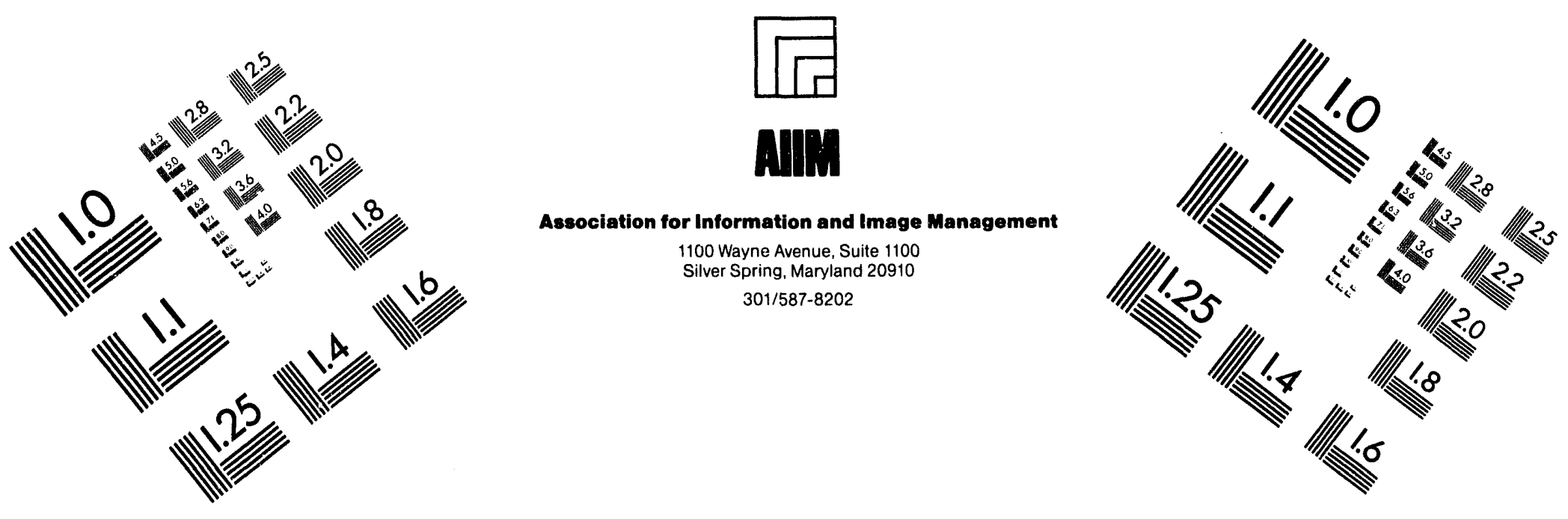

\title{
Centimeter
}

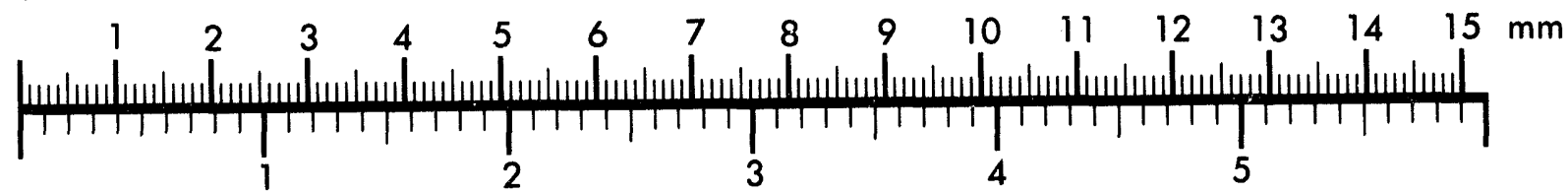
Inches
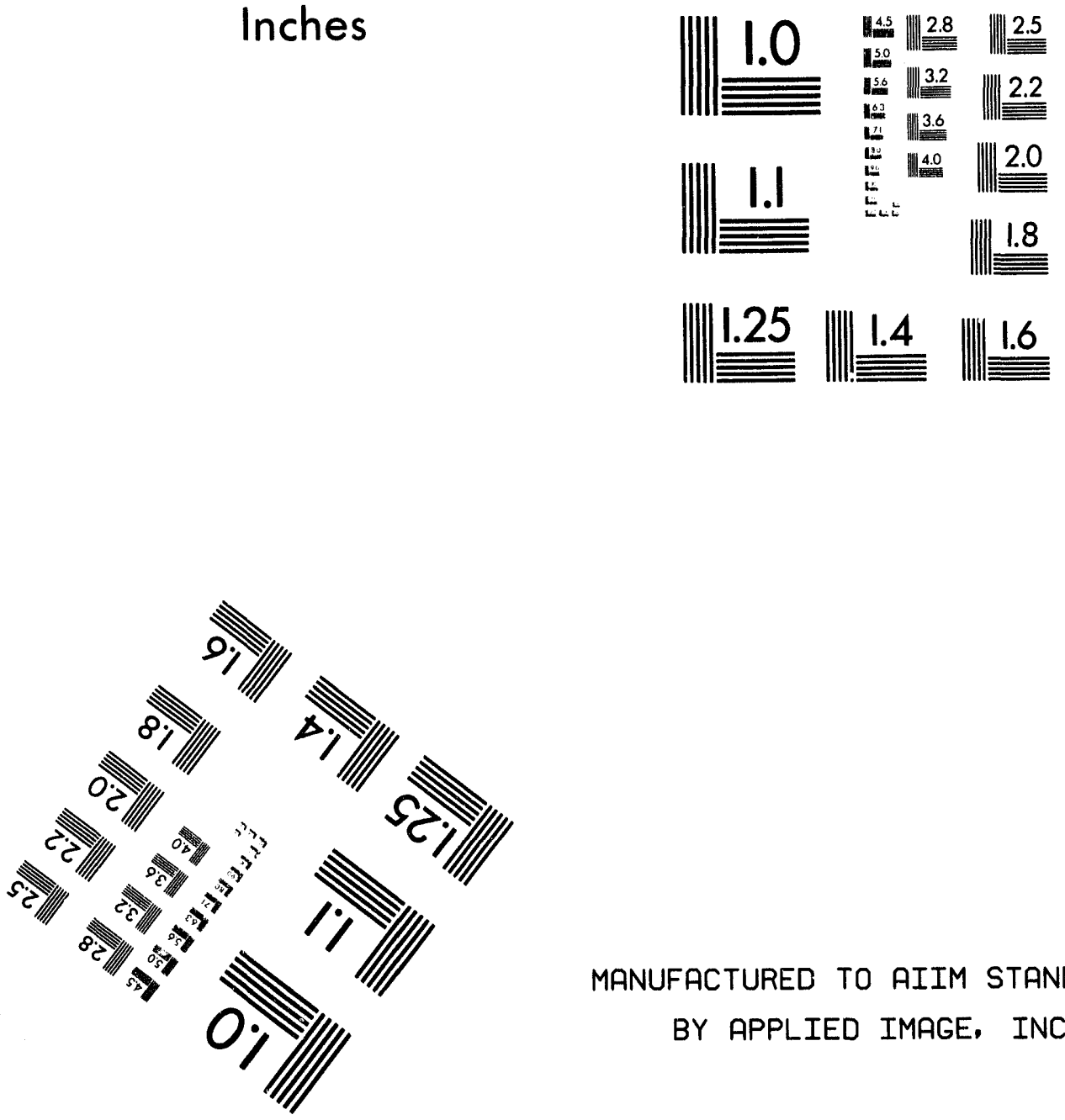

MANUFACTURED TO AIIM STANDARDS

BY APPLIED IMAGE, INC.

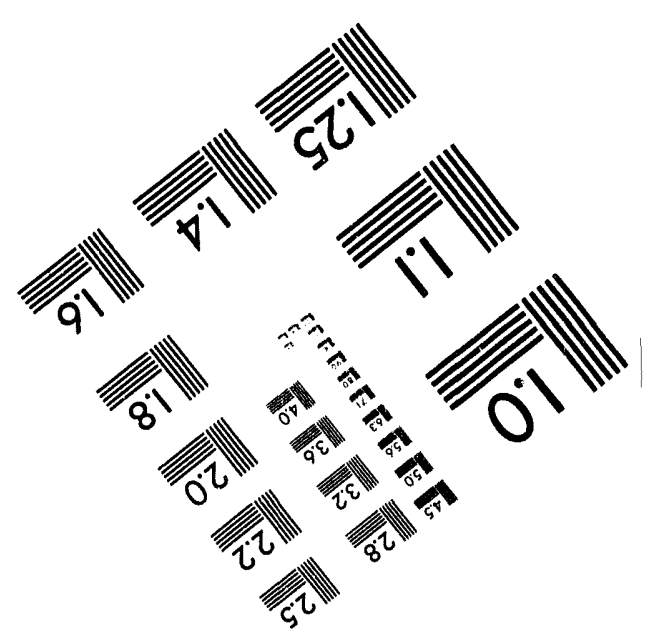



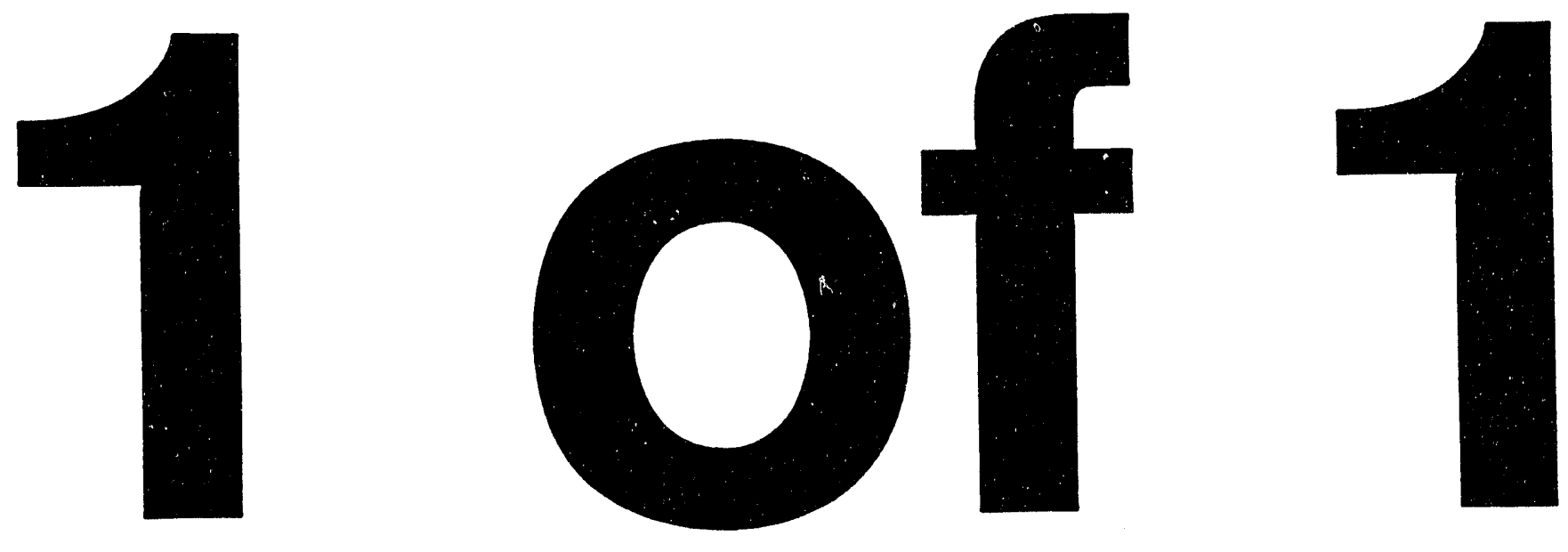
WHC-EP-0769

Revision 1

\section{Task E Container Corrosion Studies: Annual Report}

L. R. Bunnell

L. A. Doremus

J. B. Topping

Pacific Northwest Laboratory

D. R. Duncan

Westinghouse Hanford Company

Date Published

June 1994

Prepared for the U.S. Department of Energy Office of Environmental Restoration and Waste Management

\footnotetext{
(2) Westinghouse P.O. Box 1970

Hantord Company Richland, Washington 99352

Hanford Operations and Engineering Contractor for the

U.S. Department of Energy under Contract DE-AC06-87RL10930
} 


\section{RELEASE AUTHORIZATION}

Document Number:

Document Tits:
WHC-EP-0769, Revision 1

Task E Container Corrosion Studies: Annual Report

August 3, 1994

August 3

Release Date:

This document was reviewed following the procedures described in WHC-CM-3-4 and is:

APPROVED FOR PUBLIC RELEASE

$* *+* * * *+* * *+*$

WHC Information Release Administration Specialist:

M. Boston

M. N. Boston

$\frac{8 / 3 / 94}{\text { (Date) }}$




\section{EXECUTIVE SUMMARY}

\section{SEP - 6 1994}

OSTI

The Pacific Northwest Laboratory is conducting the Solid Waste Technology Support Program (SWTSP) for Westinghouse Hanford Company (WHC). Task $E$ is the Container Corrosion Study Portion of the SWTSP that will perform testing to provide defensible data on the corrosion of low-carbon steel, as used in drums to contain chemical and radioactive wastes at the Hanford Site. A second objective of Task $E$ is to provide and test practical alternative materials that have higher corrosion resistance than low-carbon steel. The scope of work for fiscal year (FY) 1993 included initial testing of mild steel specimens buried in Hanford solls or exposed to atmospheric corrosion in metal storage sheds.

During FY 1993, progress was made in three areas of Task E. First, exposure of test materials began at the Soil Corrosion Test Site where low-carbon steel specimens were placed in the soil in five test shafts at depths of $9 \mathrm{~m}(30 \mathrm{ft})$. Second, the corrosion measurement of low-carbon steel in the soil of two solid waste trenches continued. The total exposure time is $\approx 500$ days. Third, an atmospheric corrosion test of low-carbon steel was initiated in a metal shed (Building 2401 W) in the 200 West Area. This annual report describes the Task $E$ efforts and provides a current status. 


\section{CONTENTS}

1.0 INTRODUCTION . . . . . . . . . . . . . . . . . . . . 1-1

2.0 SOIL CORROSION TESTING .................... 2-1

2.1 FUNCTIONAL TEST REQUIREMENTS . . . . . . . . . . . 2-1

2.2 TEST DESCRIPTION .................... . . . . . . .

2.3 PRESENT STATUS ..................... 2-2

3.0 USE OF RESISTANCE PROBES TO MEASURE CORROSION OF

LOW-CARBON STEEL ...................... . . 3-1

4.0 ATMOSPHERIC CORROSION TEST ................... . . . 4-1

4.1 FUNCTIONAL TEST REQUIREMENTS . . . . . . . . . . . . . 4-1

4.2 TEST DESCRIPTION ..................... . . . . . . . .

4.3 INITIAL DATA ..................... 4-2

5.0 REFERENCES ......................... 5-1 APPENDICES

A SOIL CORROSION TEST FACILITY INSTALLATION AND DATA COLLECTION • . A-1

B GROUND-PENETRATING RADAR SURVEY . . . . . . . . . . . . B-1 


\section{LIST OF FIGURES}

2-1 Portion of Hanford Map Showing Location of Soil Corrosion

Test Site North of 200 West Area................ 2-3

2-2 Shaft Layout, Showing Instrumentation and Retrieval Schedule . . . 2-4

2-3 Corrosion Specimens Secured to Hexagonal Polyethylene Block

with Nylon Screws ................... 2-5

2-4 Specimen Block Centered in Polyvinyl Chloride Pipe,

Ready for Burial . . . . . . . . . . . . . . 2-6

2-5 Instrument Shaft Details . . . . . . . . . . . . . . 2-7

3-1 Schematic Diagram Showing Operating Principle of Resistance

Corrosion Probe ........................ 3-3

3-2 Plot of Corrosion Data Obtained from Buried Resistance Probes . . . 3-4

4-1 Schematic Diagram of Experimental Setup for Measuring

Atmospheric Corrosion of Low-Carbon Steel . . . . . . . . . 4-4

4-2 Initial Data from Atmospheric Corrosion Experiment, Showing

Temperatures Measured on Sides of Both Drums,

Plus Ambient Temperature ................. 4-5

4-3 Initial Data from Atmospheric Corrosion Experiment, Showing

Temperatures at Side, Top and Bottom of Sand-Filled Drum . . . . . 4-6

4-4 Initial Data from Atmospheric Corrosion Experiment, Showing

Relative Humidity and Output of Wetness Sensor Elejent . . . . . 4-7 


\section{WHC-EP-0769 REV 1}

\section{LIST OF TERMS}

DOE

DOT

FY

GPR

NIST

PNL

PVC

SWTSP

TRU

WHC

U.S. Department of Energy

U.S. Department of Transportation

fiscal year

ground-penetrating radar

National Institute for Standards and Technology

Pacific, Northwest Laboratory

polyvinyl chloride

Solid Waste Technology Support Program

transuranic

Westinghouse Hanford Company 
TASK E CONTAINER CORROSION STUDIES: ANNUAL REPORT

\subsection{INTRODUCTION}

A standard practice at the Hanford Site and other U.S. Department of Energy (DOE) sites associated with atomic weapons materials production has been to dispose of certain classes of waste materials by packaging them in wooden or fiberglass boxes or in standard U.S. Department of Transportation (DOT) steel drums, followed by soil burial. Initial burial practices allowed direct contact between the soil and the waste container. Subsequent practices employed an asphalt concrete pad under the containers and a layer of polyethylene sheeting between the pad and soll. The mosi recently generated waste that requires storage prior to disposal is stored in above-ground buildings. To meet the transuranic (TRU) disposal criteria of DOE Order 5820.2A, Radioactive Waste Management (DOE 1988), the TRU fraction of these wastes must be retrieved and sent to a federal repository for final disposal.

To properly support disposal and retrieval efforts, the corrosion rates of low-carbon steel in Hanford soils should be determined by defensible methods. WHC-EP-0408, A Review of the Hanford site Soll Applicable to Solid Waste Containers (Divine 1991), compiles the few reported values for corrosion rates in Hanford soils. Based on the values in WHC-EP-0408, some or all of the direct-buried (soil-contacted) steel drums may, have been breached by corrosion. It is important to know the condition of soil-contacted drums so that the necessity and timing of retrieval efforts can be assessed. The corrosion of steel drums in scil results from a complex mixture of mechanisms, some of which are not encountered in usual aqueous corrosion situations. For example, soil moisture (both the amount of water and the ions dissolved in $i t$ ) and aeration are parameters of prime importance in determining corrosion rates. Although limited laboratory-scale testing is possible, there is no substitute for direct soil burial to estabilsh defensible corrosion rates for the materials and soils under consideration.

Pacific Northwest Laboratory (PNL) ${ }^{1}$ is conducting Task E, the Container Corrosion Study portion of the Solid Waste Technology Support Program (SWTSP) for Westinghouse Hanford Company (WHC). The objective of Task $E$ is to perform testing that will provide defensible data on the corrosion of low-carbon steel as used in direct-buried drums that contain chemical and radioactive wastes at the Hanford Site. A second objective is to provide and test practical alternative materials having higher corrosion resistance than low-carbon steal. The fiscal year (FY) 1993 workscope for Task E included the testing of low-carbon steel buried in Hanford soils or exposed to atmospheric corrosion in metal storage sheds.

'Pacific Northwest Laboratory is operated by Battelle Memorial Institute for the U.S. Department of Energy under Contract DE-AC06-76RLO 1830. 
WHC-EP-0769 REV 1

This page intentionally left blank. 


\subsection{SOIL CORROSION TESTING}

\subsection{FUNCTIONAL TEST REQUIREMENTS}

1. Test specimens should represent the actual material used for drums at the Hanford Site. Low-carbon steel drums exposed to soil are protected by a layer of epoxy or enamel paint and therefore some specimens are covered with undamaged paint, while others had a damaged paint covering. Because corrosion will be largely confined to small areas, another drum specimen was stripped of a!l paint so that standard weight-change methods could be used to quantify the corrosion rate. Specimens cut from galvanized drums were also included to demonstrate the effectiveness of zinc coatings. Stainless steel drums might have been used for some critical wastes, so suitable specimens were included in the specimen mix. For comparison with higher-cost material, bare Type $304 \mathrm{~L}$ stainless steel was also included in the total of five different coupon types.

2. Specimens should be placed at several depths, up to $9 \mathrm{~m}(30 \mathrm{ft})$ below grade, using a method allowing reliable retrieval. The method for installing specimens, as used by the National Institute for Standards and Technology (NIST), is to place them in a trench (Romanoff 1957). The depth of such trenches is typically less than $2 \mathrm{~m}(6 \mathrm{ft})$. The greater burial depth of the this study was, however, well beyond the safe limits of the trench method, so drilled holes were used as the most practical alternative to trenching.

3. The soil in which the specimens were placed was a type and structure similar to the soil in burial ground areas. Therefore, the test site was as close as practical to the burial grounds, yet was not disturbed by disposal operations.

4. Soil from the site was characterized for comparison of observed corrosion rates with those measured at other sites.

5. During the test, data was taken on soil temperature, soil gases (because of their effect on local redox conditions), and soil moisture.

6. Real-time data on corrosion of low-carbon steel in the soil at different depths is desirable.

\subsection{TEST DESCRIPTION}

A site that met the functional test requirements is located near the 200 West Area. This site was surveyed, and a Cultural Resources Survey was also performed. There were no findings of significant artifacts. The location of this test site is shown on the map in Figure 2-1. As the time for shaft construction approached, it was discovered that the site was within an exclusion zone for nearby meteorological towers. To avoid interfering with the meteorological work, the site of the test shafts was moved from the 
original center location to the southwest corner of the surveyed area. This shift, shown in the inset map, proved efficient in terms of easy road access for drilling equipment and later field work. The surveyed coordinates of the original test site are shown in the inset.

Placing specimens at known depths to $9 \mathrm{~m}(30 \mathrm{ft})$ and retrieving them without damage is a substantial challenge. Several concepts were considered, and the one pictured in Figure 2-2 was chosen as the most workable. The specimens were attached to polyethylene blocks with nylon screws to avoid any galvanic corrosion effects. A hexagonal block with attached specimens is shown in Figure 2-3. These specimen carriers were lowered into drilled shafts lined with slotted polyvinyl chloride (PVC) casings, and the soll removed from that level was carefully backfilled. The casing will act as a guide for retrieval, when a core-barrel drilling tool is used to remove soil and capture the specimen carrier. Typical retrieval times, differing by factors of two, are illustrated in Figure 2-2. Burial times of up to sixteen years could be provided by six shafts.

When the requirement that the soil test conditions simulate the real case as closely as possible was considered, a flaw was found in the slotted PVC pipe. Al though the slots allow horizontal movement of moisture through the soil, the pipe also allows vertical moisture movement through the test soil at a rate probabiy different than the actual soil. Concerns over this moisture movement prompted a modification of the placement technique. Instead of using the PVC pipe as a continuous casing, the pipe was cut into $0.6-m(2-\mathrm{ft})$ lengths that were used as containers. The soil was carefully packed around the specimens at the surface level, and the soil will provide additional packaging during retrieval operations. A modified specimen assembly is shown in Figure 2-4. Soil from the installation depth was packed around the specimen, and the assembly was then lowered into the shaft, which was backfilled so that the specimens were placed at the intended depth. Backfiling and installation was repeated until all specimens were in place, and shaft locations were permanently marked.

The soil enyironment in which specimens were buried was characterized in two ways: (1) soil sampled from the shafts was categorized according to standard soil science methods, and (2) soil temperature, soil moisture, soil gases, and the corrosion rate of low-carbon steel were measured at several depths in an instrumentation shaft placed at the center of the specimen shafts. Figure 2-5 shows this instrumentation shaft in cross section, indicating the sensors and their depths. Also shown is a PVC pipe used to provide access for a neutron probe that will be lowered to measure soil moisture in-situ. The neutron probe will be used instead of the traditional gypsum blocks indicated in Figure 2-2.

\subsection{PRESENT STATUS}

A total of six shafts (five for specimens, one for instruments) instead of seven were drilled in FY 1993. The seventh shaft will be drilled during retrieval operations in July of FY 1994. Specimens from the seventh shaft will be retrieved after sixteen years exposure under the current test plan. 
Figure 2-1. Portion of Hanford Map Showing Location of Soil Corrosion Test Site North of 200 West Area.

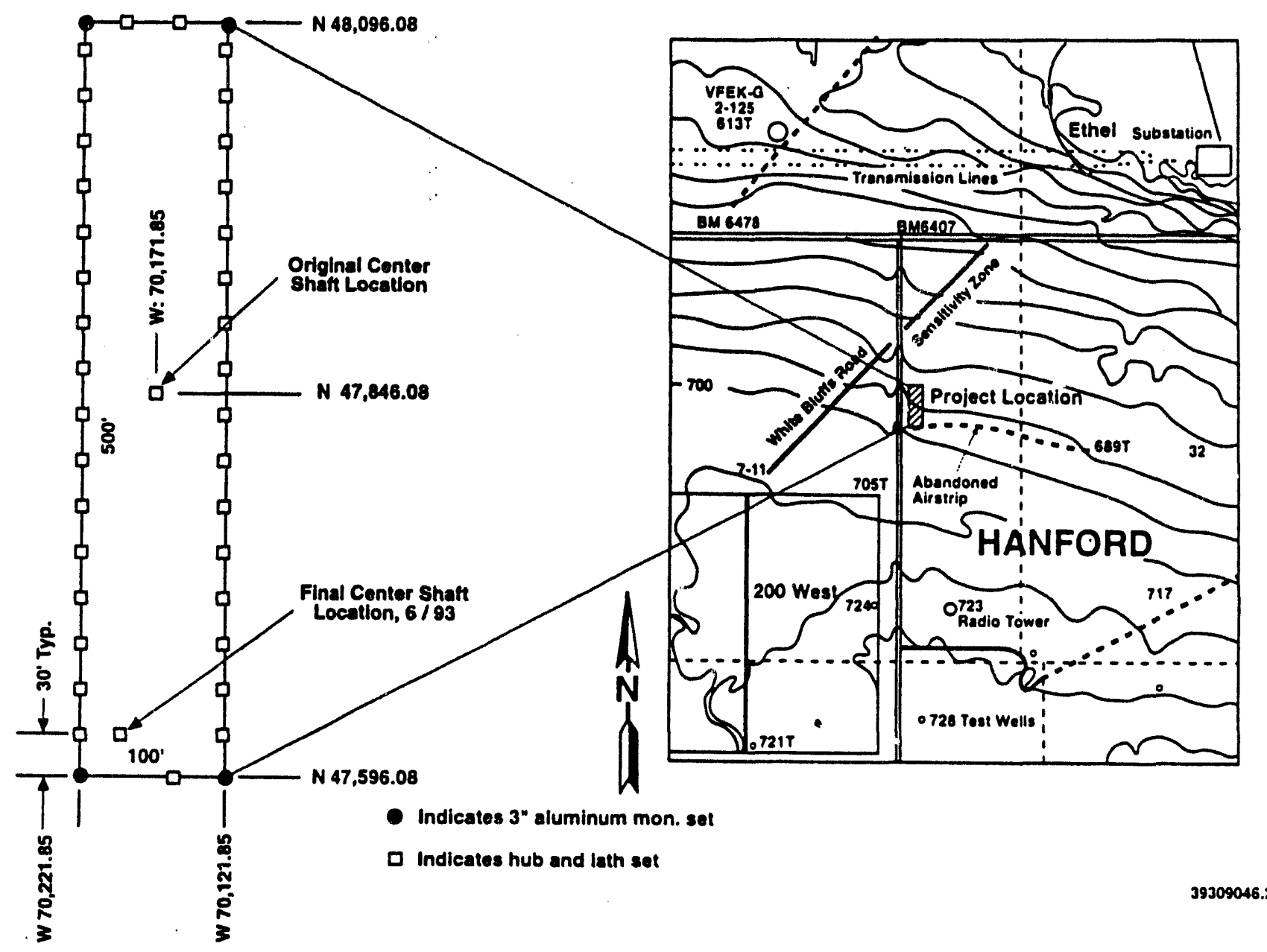


Figure 2-2. Shaft Layout, Showing Instrumentation and Retrieval Schedule.

$\begin{array}{cc}\text { Backup } & 0.5 Y\end{array}$

$\stackrel{2 r}{0}$

Instrument

Shaft

$4 Y$

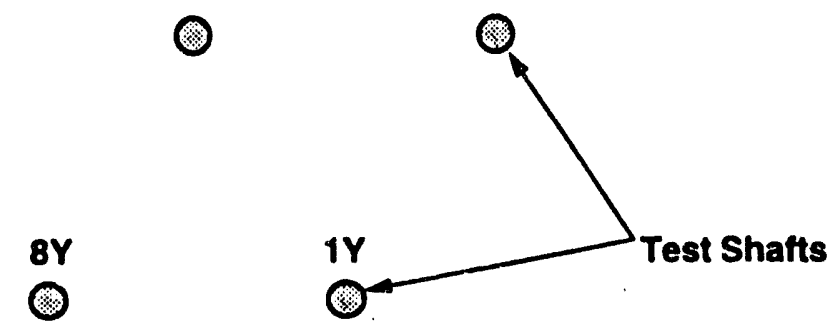

Top View
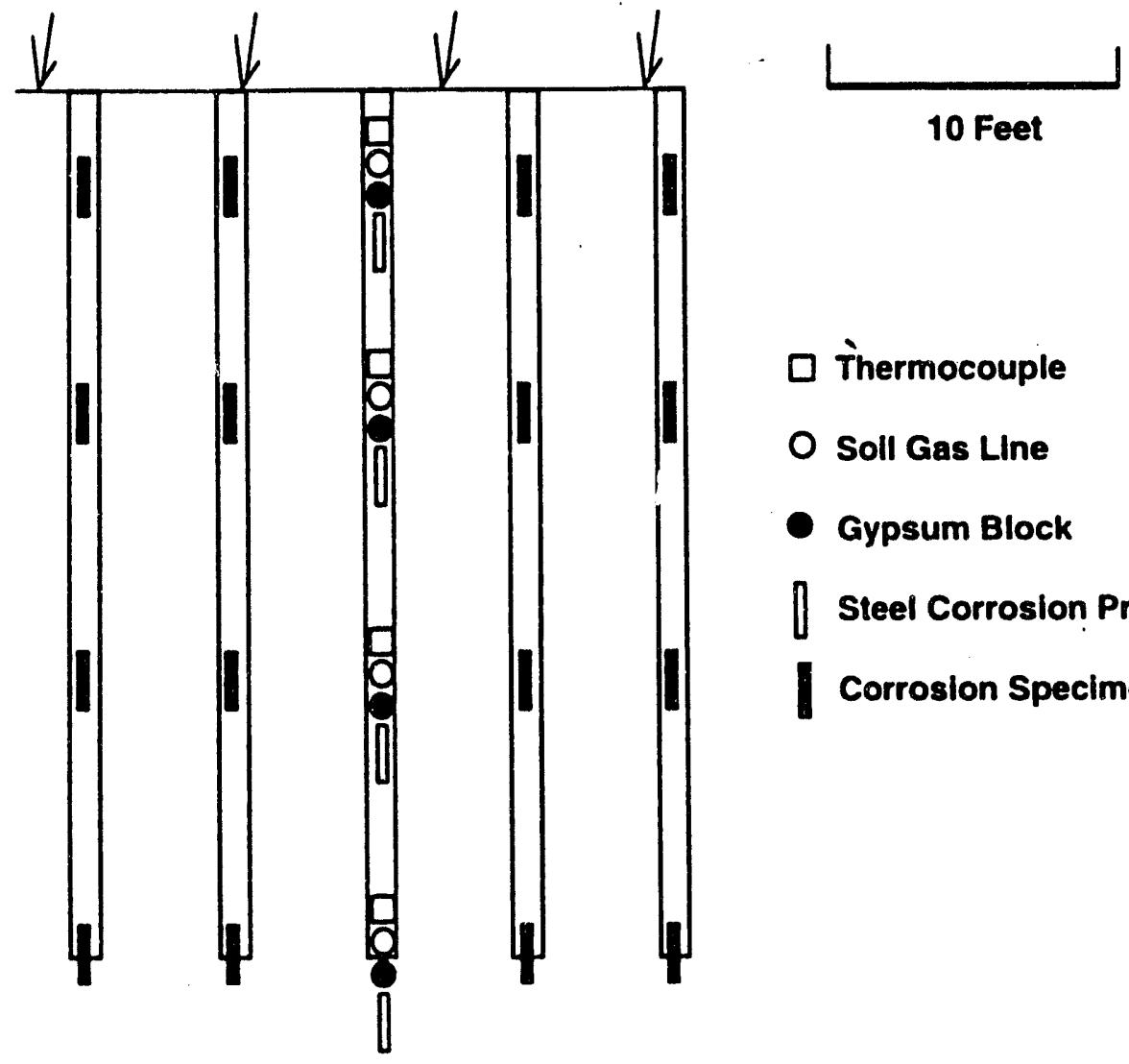

10 Feet

$\square$ Thermocouple

O Soll Gas Line

- Gypsum Block

I Steel Corrosion Probe

Corrosion Specimen Carrier

Side View

39112008.1 
Figure 2-3. Corrosion Specimens Secured to Hexagonal

Polyethylene Block with Nylon Screws.

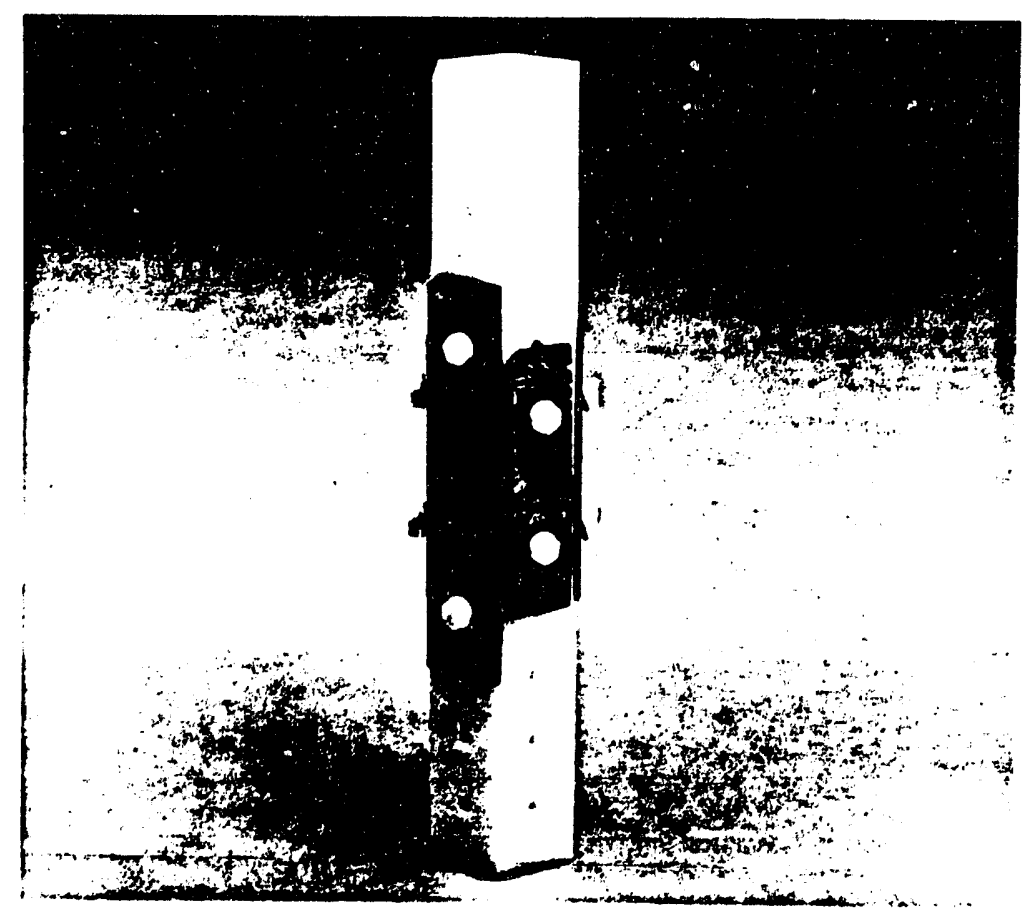


WHC-EP-0769

Figure 2-4. Specimen Block Centered in Polyvinyl Chloride Pipe, Ready for Burial.

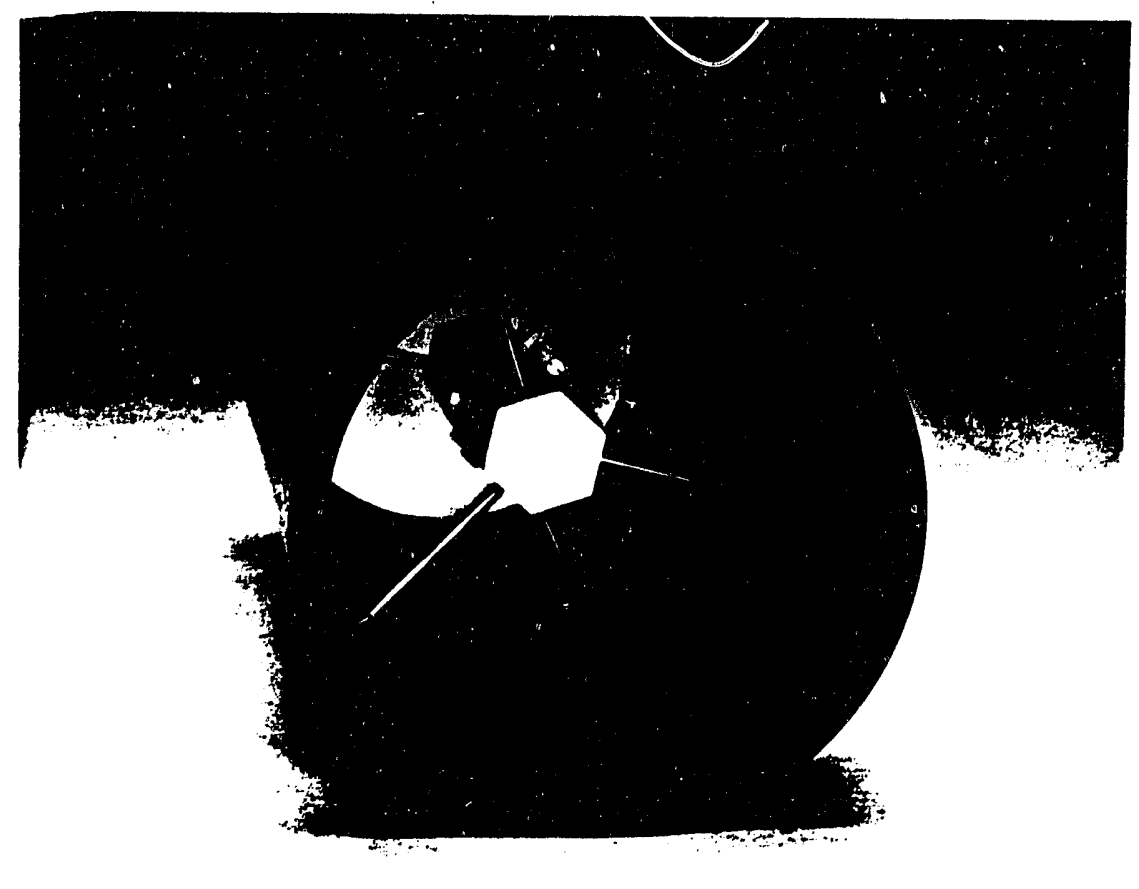


Figure 2-5. Instrument Shaft Details.

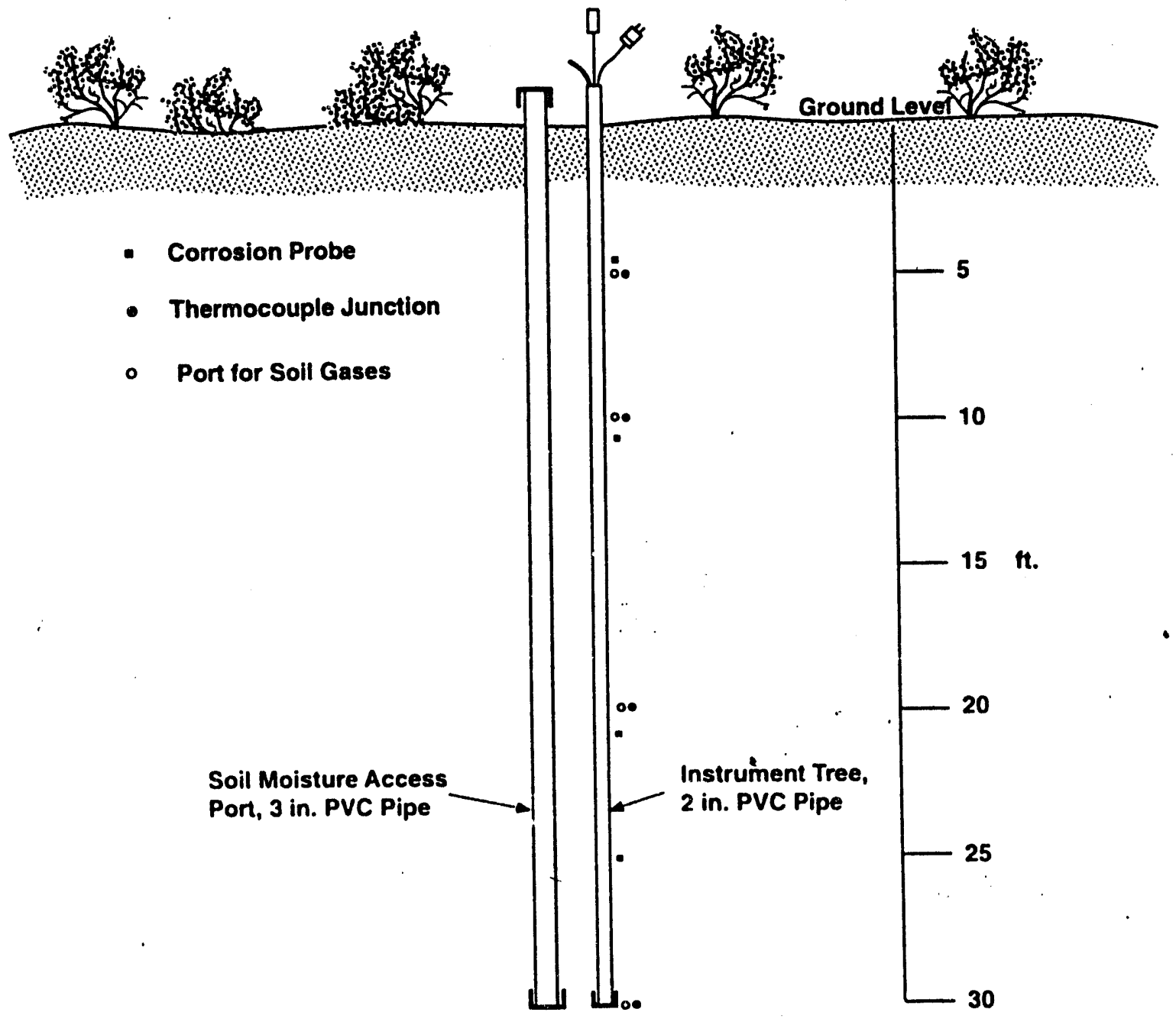

39309046.1 


\section{WHC-EP-0769 REV 1}

This page intentionally left blank. 


\subsection{USE OF RESISTANCE PROBES TO MEASURE CORROSION OF LOW-CARBON STEEL}

To gain experience using simple resistance probes to measure corrosion in soils, as well as to accumulate data on local corrosion rates, a total of six probes are presently installed in the sidewalls of two active, open trenches in the 200 West Area. Corrosion rate information obtained from these probes is based on the change in electrical resistance of a metal element of known dimensions as metal is lost to corrosion. These probes are made in a variety of configurations for different applications, such as insertion into pipes or chemical vessels, in which case the corroding specimen is usually in a tubular or wire configuration. The probes for this test are epoxy-sealed units and the specimen is in the form of a strip. In use, the resistance of the metal is measured using a sensitive bridge circuit. The probe also includes a coupon of the same metal, shielded from the environment. The corroding element will increase in resistance, the shielded one should not. By connecting both coupons as legs in a Kelvin bridge, the loss of metal can be accurately measured. The shielded coupons also provide temperature compensation so that ambient temperature does not influence the readings. Figure 3-1 shows the type of probe used for the soil corrosion work. The corroding metal is ASME 1008 low-carbon steel and is $0.012 \mathrm{~cm}(0.005$ in.) thick so that perforation will occur within about a year at maximum anticipated corrosion rates.

Because the soil corrosion probes directly measure metal loss, interpretation of the measurements is very straightforward. To provide valid data, the corrosion should be uniform, especially in this situation where perforation of drums is the issue of concern. If the metal corrodes uniformly, the average rate will be fairly close to the maximum rate. Such corrosion behavior is generally expected from unprotected low-carbon steel. Pits, if developed, are usually relatively broad and less than three times the depth of uniform corrosion. Before the probes can be used with confidence, the presence of only broad, shallow pits should be confirmed by examining retrieved probe elements.

Four probes were installed in 1992, two in Trench 8 of the 3AE Burial Ground (serial numbers [S/N] 066 and 068 ) and two in Trench 24 of the 218 W4C Burial Grounds (S/N 204 and 205). Both trenches are in the 200 West Area. The trenches were chosen on the basis of being nearly empty, ALARA, relative inactivity and close proximity to roads for simple long-term access. The soil in the two trenches was very different: in Trench 24, (where probes 066 and 068 were buried) the soil was coarse dark-colored sand, while soil in Trench 8 (probes 204 and 205) was a mixture of fine sand and coarse gravel containing rocks up to $10 \mathrm{~cm}$ ( 4 in.) in diameter. The probes were buried $-0.3 \mathrm{~m}(\approx 1 \mathrm{ft})$ deep in the trench wall, near the floor, deep enough to be exposed to nearly $100 \%$ relative humidity from soil moisture. When metals are exposed to moisture from the air, $50 \%$ to $60 \%$ humidity is considered necessary for active corrosion. 
When initial data from these probes indicated a very low corrosion rate, two additional probes ( $S / N 1830$ and 1835 ) were installed in April 1993, $\approx 1.2 \mathrm{~m}$ $(\approx 4 \mathrm{ft})$ deep in trench 24 , where digging was easier and the finer sand provided a more consistent environment. All probes have been monitored on a monthly basis, except when prevented by weather or other unavoidable factors. Figure 3-2 shows the results to date. The corrosion rate calculated from the four probes buried for 520 days is about $0.009 \mathrm{~mm} / \mathrm{yr}(0.34 \mathrm{mils} / \mathrm{yr})$. This corrosion rate is low compared to expected long-term rates for low-carbon steel in Hanford soils, which averaged from 0.08 to $0.15 \mathrm{~mm} / \mathrm{yr}$ ( 3 to $6 \mathrm{mils} / \mathrm{yr}$ ) in the report by Divine (1991). The corrosion rate measured by the deeper buried probes is close to $0.03 \mathrm{~mm} / \mathrm{yr}$ ( $1 \mathrm{mi} / \mathrm{s} / \mathrm{yr}$ ), perhaps indicating the original probes were not buried deeply enough for consistent exposure to soil moisture. Data collection from the buried probes will continue, as will measurements from other similar probes installed at the test site. 

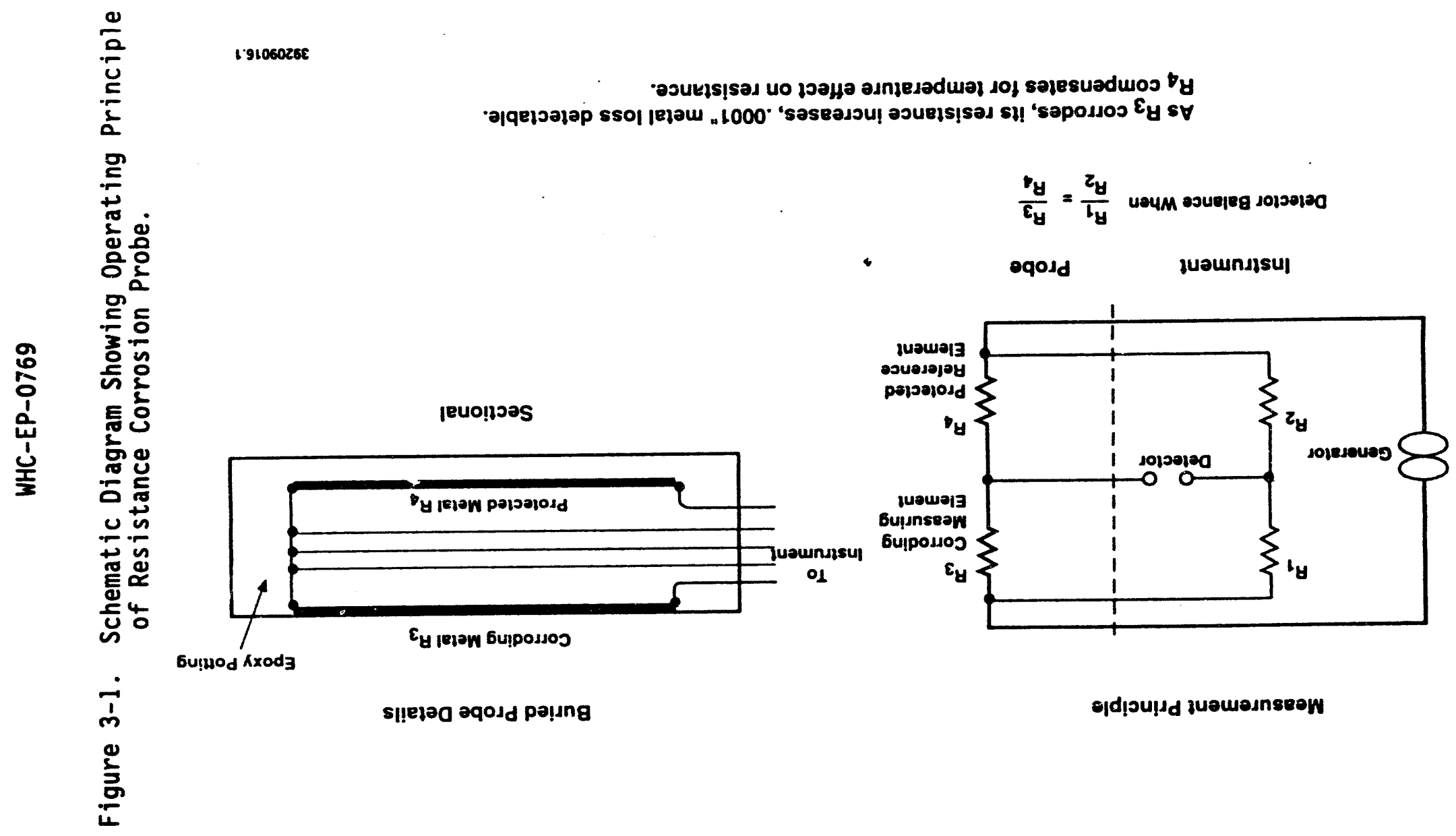
Figure 3-2. Plot of Corrosion Data Obtained from Buried Resistance Probes.

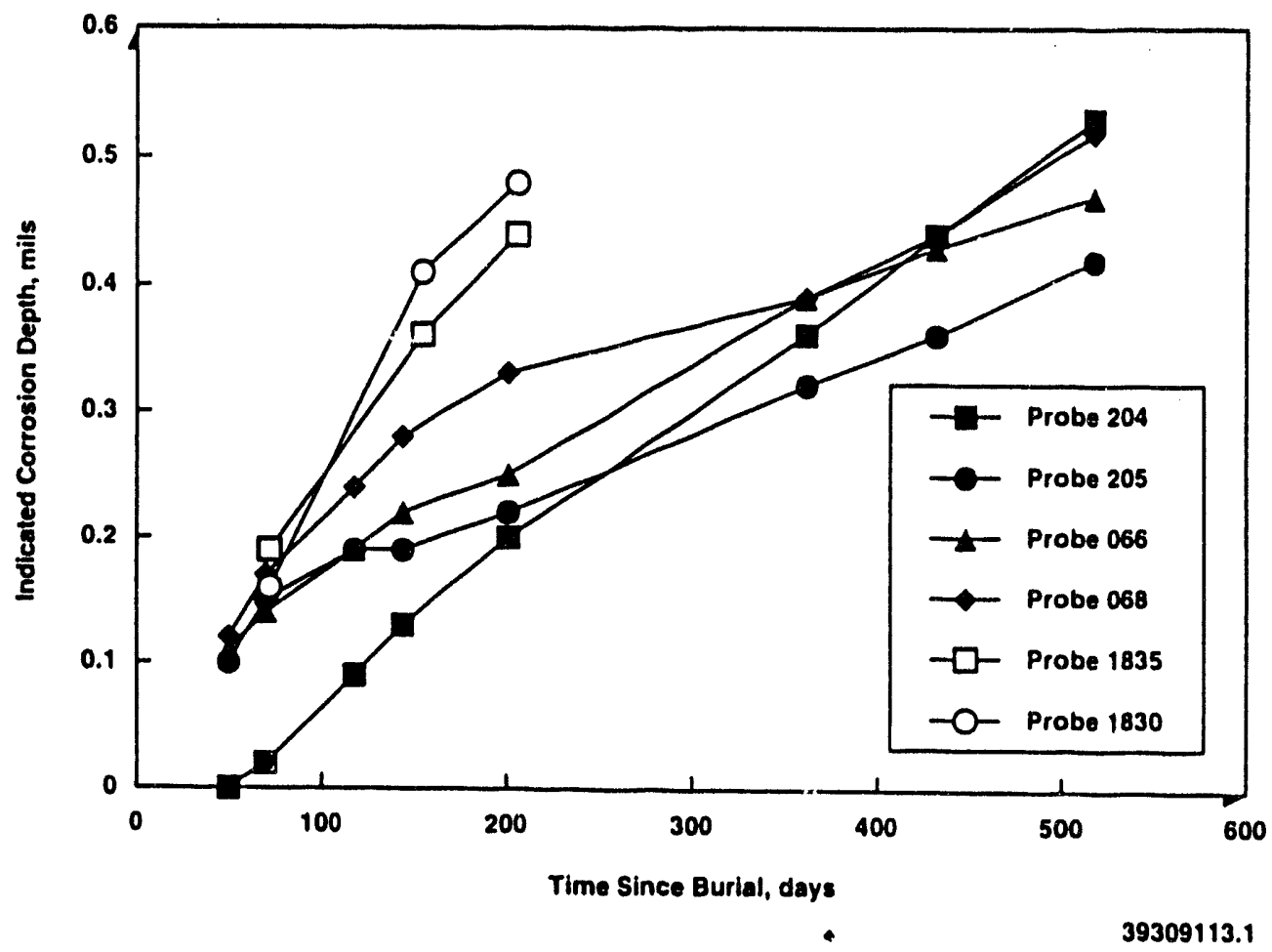




\subsection{ATMOSPHERIC CORROSION TEST}

Current land disposal methods for certain waste types at the Hanford Site involve packaging in standard DOT steel drums and temporary storage in metal buildings. The drums are protected by a coating of epoxy paint on external surfaces, but the coating is likely to be damaged during handing. The buildings are not heated or cooled, but are provided with forced air ventilation. Very little corrosion is expected to occur during the storage period, which may last for up to ten years, but the lack of measured values under realistic conditions prompted atmospheric corrosion testing.

\subsection{FUNCTIONAL TEST REQUIREMENTS}

To obtain data useful for estimating likely corrosion of drums during storage, the following requirements were met:

1. The tested material was sampled from actual DOT drums, and was tested under several conditions: covered with intact paint, covered with damaged paint, stripped of all paint, galvanized with zinc, and covered with a damaged zinc coating.

2. The specimens were exposed to heating and cooling cycles that mimic those experienced by an actual filled drum.

3. The temperature and humidity were monitored during the test, and a method for detecting any water film was used.

4. A real-time method for assessing corrosion rate was used.

5. The test instruments were operable on a stand-alone basis in a chosen bullding (because bulldings are not provided with electrical power) and were movable within the building, if needed, to be compatible with normal operations at the Central Waste Complex in the 200 West Area.

\subsection{TEST DESCRIPTION}

Specimens were cut from actual DOT waste drums ordered for use at the Hanford Site. Paint was stripped from specimens to be exposed in the bare state, using a common methylene chloride paint stripper. Note: the same material was used to strip paint from bare specimens used in soll corrosion studies. The paint condition on some specimens was damaged by scribing a $1.3-\mathrm{cm}(0.5-\mathrm{in}$.$) grid design that cut through paint to bare metal. Because$ drums are not currently coated on inner surfaces as-received, the inner surfaces were coated with a paint known to be very resistant to corrosion. 2

'Jasco brand Paint and Epoxy Remover, Jasco Chemical Corporation, Mountain View, California.

Hunter Green Krylon spray paint, Sherwin-Williams Company, Solon, Ohio. 
Specimens were attached to both the curved and flat surfaces of DOT 17-H waste drums, using nylon screws inserted into tapped holes to eliminate possible gaivanic corrosion. The specimens placed on curved and flat surfaces were cut froni: the sides and top, respectively, of the source material drums. Special washers were used between the specimens and the bolts to avoid forming crevices where corrosion is often enhanced. These same washers were used, for the same reason, for specimens used in the soll corrosion tests. To mimic the thermal cycles encountered by metal in the drums, the drums on which specimens were placed were filled with sand or with dry rags to represent high or low

thermal mass, respectively. The temperature of the drum with the higher thermal mass is expected to rise more slowly than the outside temperature and is thus more likely to produce a film of condensed water if the air is sufficiently humid. The water film would accelerate corrosion.

Temperature and humidity were measured by thermocouples mounted on the drums and by an electrical humidity probe, respectively. The instruments were connected to a data logger capable of sustained operation on battery power. Figure 4-1 shows the test setup. Instrumentation al so included two electrical resistance corrosion probes to monitor slow corrosion on surfaces. The active element in these probes is low-carbon steel, in the form of a $0.05-\mathrm{cm}-(2-\mathrm{mi}][0.002-$ in. -$])$ thick sheet. Because probe sensitivity is inversely proportional tc sheet thickness, the thin elements should be sensitive detectors of corrosion. The corrosion probes must be read manually using a precision potentiometer. These readings will be performed monthly as logged data is downloaded.

\subsection{INITIAL DATA}

The Atmospheric Corrosion Test was operational on June 18, 1993. Data from the first 87 days of operation were transferred to magnetic media in late August 1993. The data appears to be consistent, as seen in Figures 4-2, 4-3, and 4-4, which indicate the type of information avallable from the instrumentation on the test rig. Figure 4-2 reflects temperatures recorded during the highest-temperature portion of the test period. These measurements were taken using a thermocouple mounted on the side of sand-filled and rag-filled drums. The daily temperature fluctuations are shown, and it is clear that the skin temperature of the rag-filled drum varies more than that of the sand-filled drum, which is reasonable considering the higher heat capacity of the sandfilled drum. The temperatures of both drums did not change as much as the ambient air temperature, also because of their thermal mass.

Temperatures measured on the sand-filled drum at top, side, and bottom positions are plotted in Figure 4-3. While side and top temperatures are in close agreement, the bottom thermocouple is shielded from air movement and so the temperature swings are damped. The relative humidity and wetness sensor outputs are plotted for the same period in Figure 4-4. The humidity never rose above $60 \%$ and the wetness sensor output tracked the humidity closely. The design of the wetness sensor is such that its conductivity will increase by a factor of at least 1,000 if there is ever a water film over its surface; this indication was never seen during the period of operation to date. The fluctuations seen in Figure 4-4 are at the noise level, and do not indicate that a water film was present during the period shown. 
Operation of the Atmospheric Corrosion Test Rig is planned to continue over the next several years, and recorded data will be read monthly.

Resistance-type corrosion probes will be read manually during these monthly visits, and the data will be plotted to indicate a real-time corrosion rate. During data readout, the surface-mounted specimens will be inspected and any prominent changes will be documented by photographs. Two complete sets of specimens will be retrieved during FY 1994, one at six months exposure and another after one year. 
Figure 4-1. Schematic Diagram of Experimental Setup for Measuring Atmospheric Corrosion of Low-Carbon Steel.

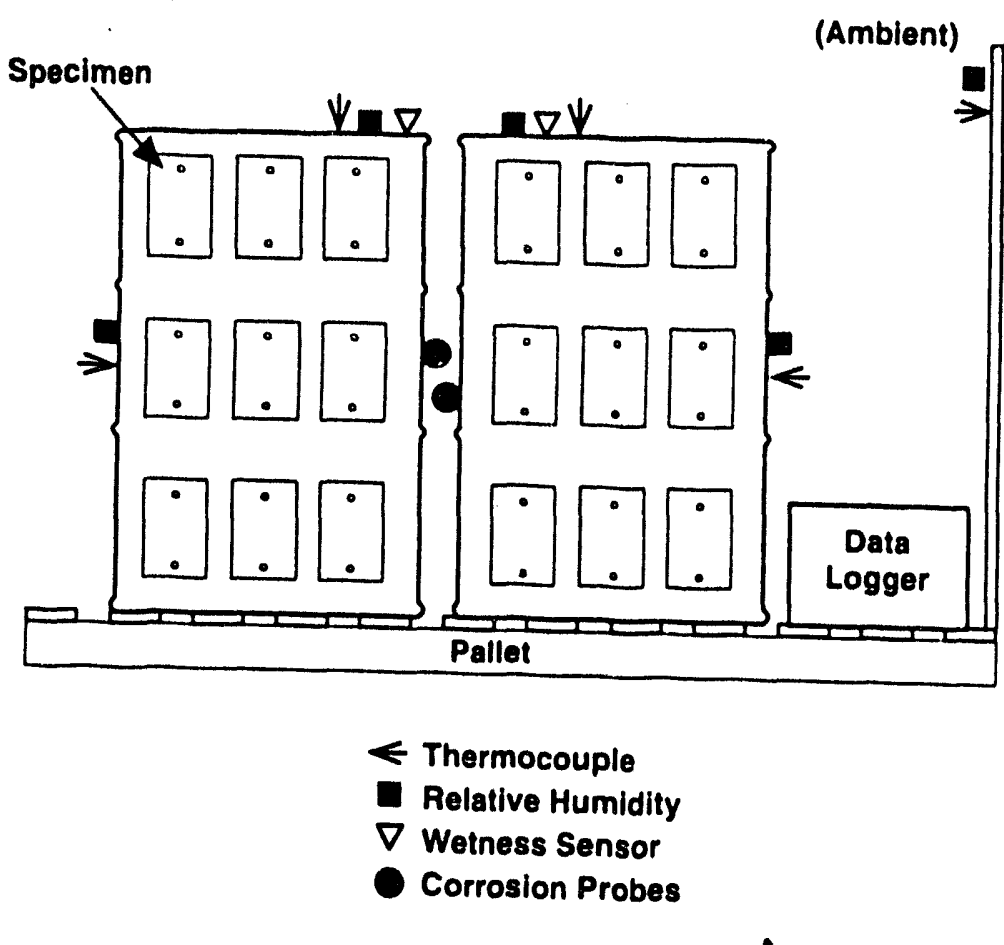

39303100.1 
Figure 4-2. Initial Data from Atmospheric Corrosion Experiment, Showing Temperatures Measured on Sides of Both Drums, Plus Ambient Temperature.

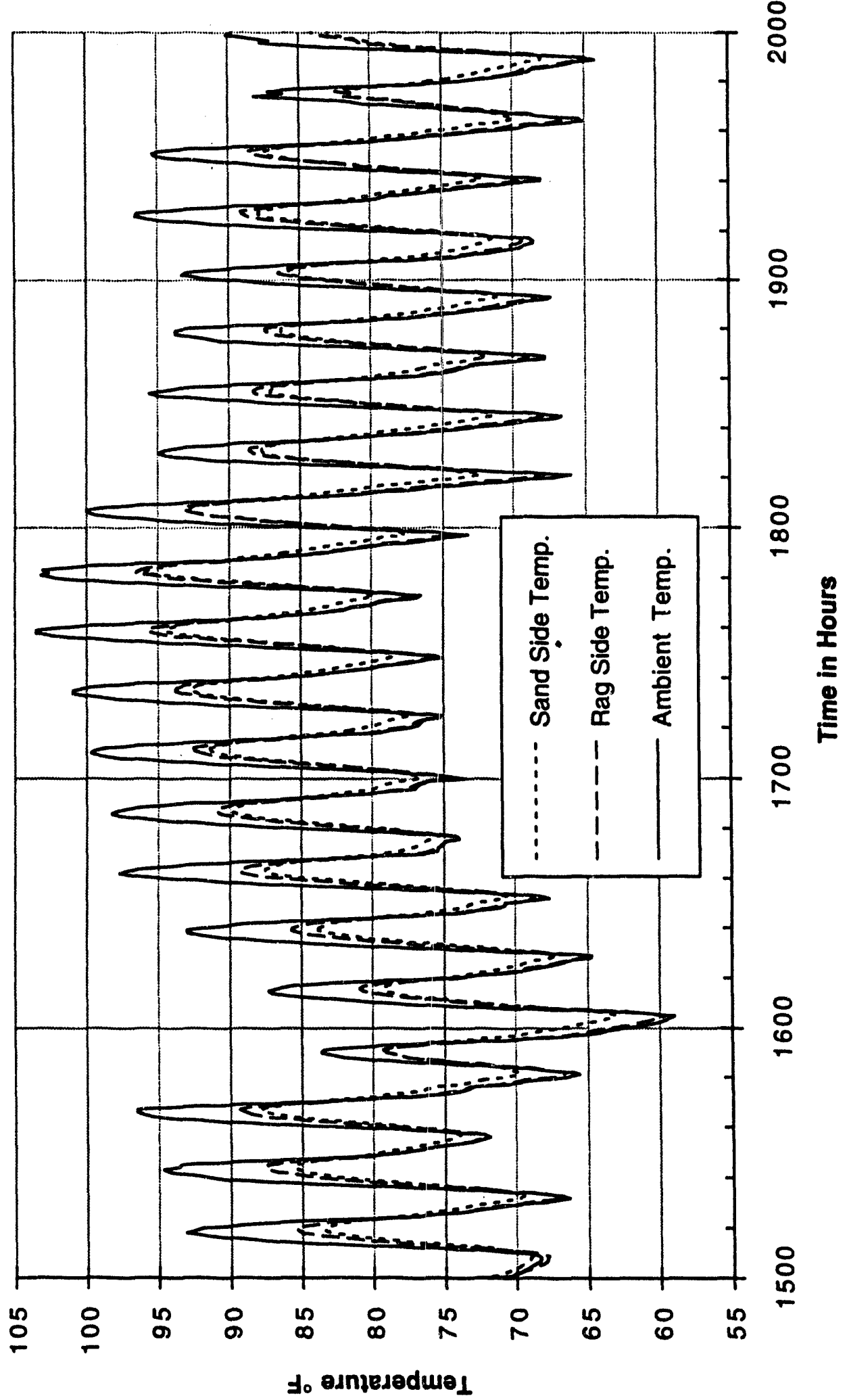


Figure 4-3. Initial Data from Atmospheric Corrosion Experiment, Showing Temperatures at Side, Top and Bottom of Sand-Filled Drum.

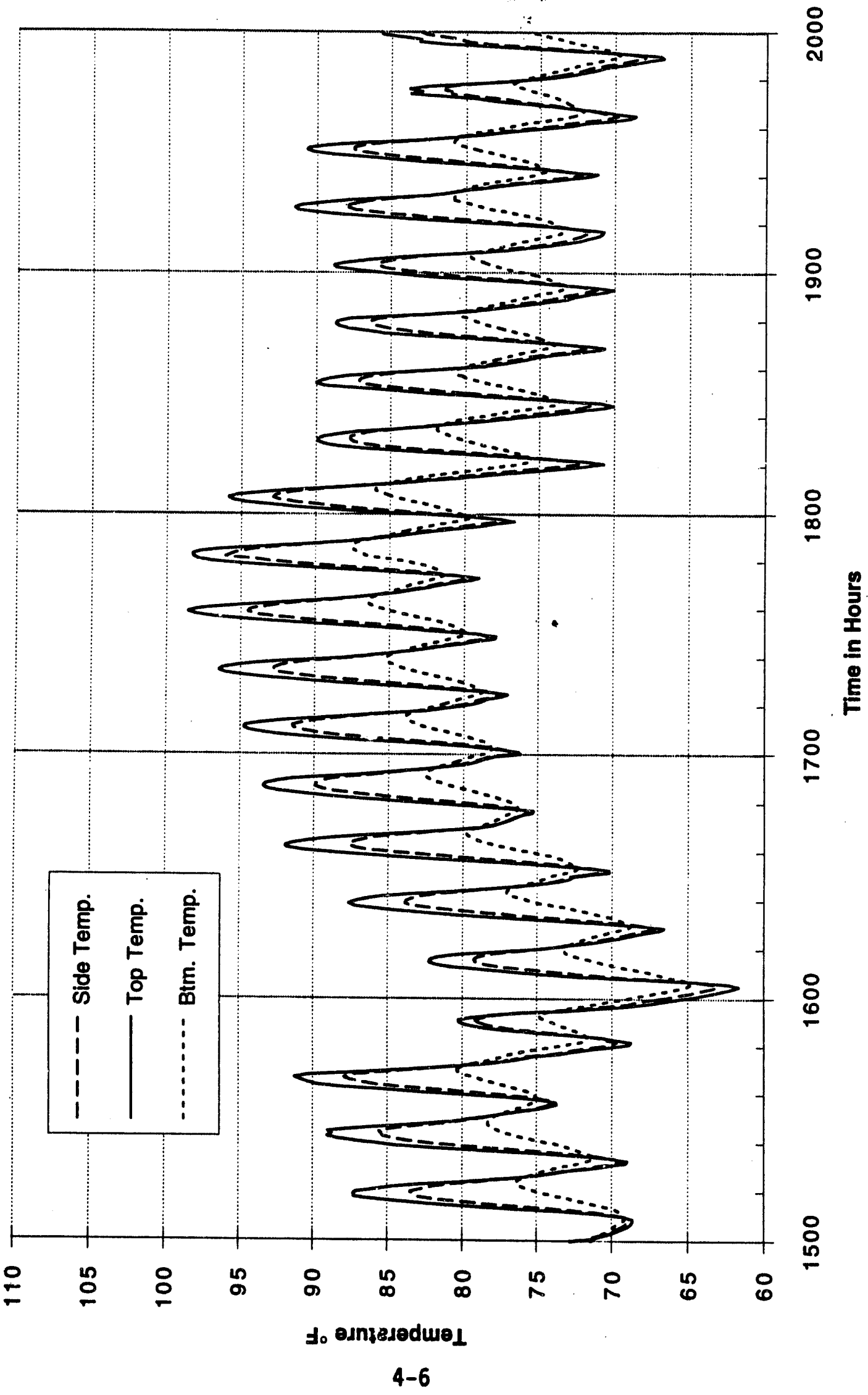


Relative Humidity

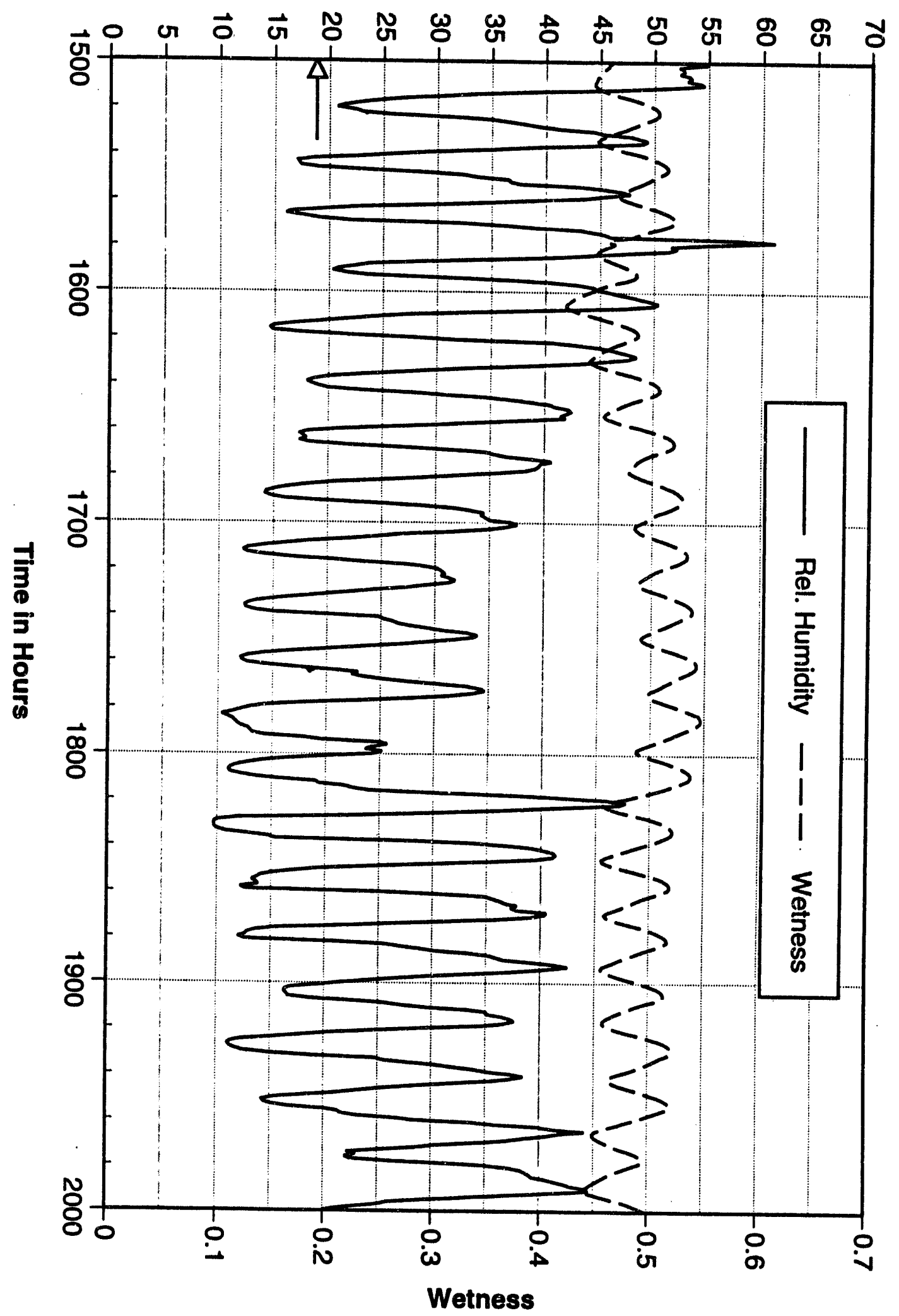

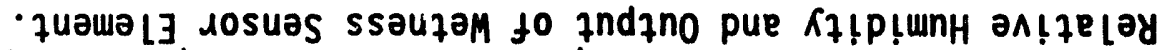

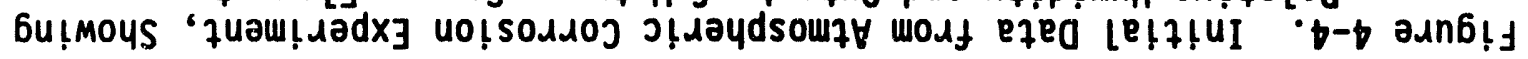


WHC-EP-0769 REV 1

This page intentionally left blank. 


\subsection{REFERENCES}

Divine, J. R., 1991, A Review of the Hanford Site Soll Applicable to Solid Waste Containers, WHC-EP-0408, Westinghouse Hanford Company, Richl and, Washington.

Romanoff, M., 1957, Underground Corrosion, National Bureau of Standards, Circular 579, U.S. Government Printing Office, Washington, D.C.

DOE, 1988, Radioactive Waste Management, DOE Order 5820.2A, U.S. Department of Energy, Washington, D.C. 
WHC-EP-0769 REV 1

This page intentionally left blank. 
WHC-EP-0769

APPENDIX A

SOIL CORROSION TEST FACILITY INSTALLATION AND DATA COLLECTION

A-1 
WHC-EP-0769

This page intentionally left blank. 


\section{SOIL CORROSION TEST FACILITY INSTALLATION AND DATA COLLECTION}

\section{A1.0 OVERVIEW OF THE WORK COMPLETED}

The effects of subsurface corrosion on different metals used for waste storage at the Hanford Site will influence the fate and performance of the storage system. To gain a better understanding of the deterioration of materials in the subsurface, metal coupons made of small squares of the different metal drum materials were placed into the ground to be monitored over extended periods. The coupons were installed at four depths in five different boreholes. After specific time intervals have elapsed, coupons from each of the boreholes will be retrieved. The coupons will then be examined to determine the effects of the corrosion undergone in the subsurface. In addition, the subsurface conditions of sediment moisture, temperature, and oxygen content will be monitored monthly over the same time period.

The subsurface corrosion study facility was constructed on the Hanford Site, in the 600 Area, as shown in Figure 1-1 of the main document. North of the Meteorologic Station, near the 200 West Area, six boreholes were drilled to a depth of $9 \mathrm{~m}(30 \mathrm{ft})$. Five boreholes were arranged in a circle, each located $6 \mathrm{~m}(20 \mathrm{ft})$ out radially from the center hole as shown in Figure A-1. Subsurface monitoring equipment was installed in the central borehole. The metal coupons were installed in the surrounding boreholes. Six coupons were mounted on "cassettes" installed at each of four depths in every borehole: at $1.5,3,6$, and $9 \mathrm{~m}(5,10,20$, and $30 \mathrm{ft})$. The cassettes are constructed from $25 \mathrm{~cm}-(10 \mathrm{in.}-)$ diameter slotted PVC pipe. Each cassette is $-0.6 \mathrm{~m}(\sim 2 \mathrm{ft})$ long, and contains one plastic frame inside the pipe. The plastic frame was used to mount the six metal coupons. The cassettes are used to identify the location in the subsurface of the metal coupons to facilitate future retrieval. Each of the boreholes were assigned numbers including 699-49-71A (the center monitored borehole), surrounded by, 699-49-71B, 699-49-71C, 699-49-71D, 699-49-71E, and 699-49-71F. The depths at which the numbered coupon cassettes were installed and the boreholes into which they were placed are listed in Table $A-1$.

The onsite geologist supervising the installation of the cassettes collected samples from four of the six boreholes for soil moisture content analyses and lithologic descriptions. Samples were collected every $1.5 \mathrm{~m}$ (5 ft), or more, if a lithologic change occurred. The well numbers from which samples were taken are 699-49-71A, 699-49-71B, 699-49-71C, and 699-49-71E.

\section{A1.1 DESCRIPTION OF FACILITY INSTALLATION}

A cable tool drilling rig was used to drill the boreholes for the installation of the cassettes and monitoring equipment. Sediments were removed from the borehole with a $30 \mathrm{~cm}$ (12 in.) diameter core barrel. Samples were collected for 1 ithologic description and moisture content analyses from the sediments within the core barrel. A $30 \mathrm{~cm}$ (12 in.) diameter carbon steel casing was driven into the borehole after the sediments were removed to prevent the borehole from sloughing in. Casing lengths of $3 \mathrm{~m}$ (10 ft) were welded on as the drilling progressed. As the borehole was dug, the excavated 
WHC-EP-0769

sediments were placed on a tarp in the same order that they were removed. The cassettes containing the metal coupons were lowered to the bottom of the borehole. Before lowering the cassettes into the borehole; they were filled with sediments representative of the surrounding formation. Once the cassettes were emplaced, sediments were shoveled by hand back into the hole in the same order that they were removed to ensure that the sediments replaced in the borehole were representative of those in the surrounding formation. As these sediments were added, the carbon steel casing was slowly back-pulled.

The cassettes that were installed into the boreholes were numbered. These numbers and the depths at which they were installed were recorded when they were emplaced, and are listed in Table A-1. Because of a lag in the communication between personnel, the first four cassettes were installed into 699-49-71B without their numbers being recorded. The numbers ilsted on Table A-1 for this borehole are estimated from memory by the field personnel.

Some events that occurred during the course of the cassette emplacement may have an influence on the findings of this study. Those events are described here for future reference. During the dally drilling activities a water truck sprayed down the entire work area to suppress dust from being blown into the air. It is likely that some portion of this water has infiltrated to the locations of the cassettes, causing a higher moisture content than would be found naturally. Before replacing the sediments and cassettes above the $6 \mathrm{~m}(20 \mathrm{ft})$ depth in the 699-49-71E borehole, it rained. The wet sediments were stripped from the sediment plle and sediment that was as dry as possible was used to backfill the borehole. However, some of the rain dampened sediment was returned to the borehole between the surface and the $6 \mathrm{~m}(20 \mathrm{ft})$ depth, which may possibly influence the coupon's corrosion at the $1.5,3$, and $6 \mathrm{~m}(5,10$, and $20 \mathrm{ft})$ depth. In addition, cassettes installed into 699-49-71E at the 1.5 and $3 \mathrm{~m}$ (5 and $10 \mathrm{ft}$ ) depths were outside during rain events, although under the cover of a table. These cassette coupons may have been buried with condensate on them. Before the sediment replacement in borehole 699-49-71F it rained overnight and the sediment added at the $9 \mathrm{~m}(30 \mathrm{ft})$ depth was moist.

\section{A2.0 DATA COLLECTED}

Data was collected over the course of the borehole drilling and following the emplacement of the cassettes containing the coupons. A description of the sediments encountered every $1.5 \mathrm{~m}(5 \mathrm{ft})$ in each borehole was recorded. Borehole logs of the daily activities, containing sediment descriptions for each borehole are included in this Appendix. From four boreholes additional samples were taken for future analyses (to be determined), moisture content determination, and to be archived in the Westinghouse Geotechnical Library. A general overview of the sediment lithologies encountered in the boreholes follows in Section A2.1. 
Sediment samples for moisture content analysis were taken from four boreholes numbered: 699-49-71A, 699-49-71B, 699-49-71C, and 699-49-71E. Moisture content samples were taken approximately every $1.5 \mathrm{~m}(5 \mathrm{ft})$. Analyses were performed after all the samples were collected and the drilling completed.

Data from the oxygen content of the sediment void spaces was collected in October 1993, two months after the cassette emplacement was completed. Soll gas oxygen measurements were taken from all the soll gas access tubes from depths of $1.5,3,6$, and $9 \mathrm{~m}(5,10,20$, and $30 \mathrm{ft})$ in the 699-49-71A borehole.

\section{A2.1 SEDIMENTS ENCOUNTERED}

Sediments encountered during drilling were all deposited very recently with respect to Geologic time. The most shallow sediments are wind blown loess, $\approx 1.2 \mathrm{~m}(\approx 4 \mathrm{ft})$ thick. Beneath the loess layer are sediments of the Hanford formation, deposited by the catastrophic floods from Lake Missoula. These sediments have probably been in place :Or less than 100,000 years.

The 1ithologies of the sediments encountered during the drilling of all of the boreholes were laterally consistent. Sediment samples were taken every five feet, and described according to the Folk 1ithologic classification (Folk 1968). From the ground surface to a depth of $\approx 1$ to $1.2 \mathrm{~m}(\approx 3$ to $4 \mathrm{ft}$ ) is the wind blown loess, classified as a muddy sand. The sediments are likely to have a high silt content with some clay present and are classified as mud because a distinction between clay and silt is not possible in the field. Although samples have been collected for archive and future study, analyses to determine what the specific components of the mud size fraction have not been done.

Underlying the muddy sand, to a depth of $\approx 2.5$ to $3.5 \mathrm{~m}(\approx 8$ to $12 \mathrm{ft})$ is a layer of coarse grained sediments classified as a muddy sandy gravel. About half of the clasts in this layer are gravel size, greater than $2 \mathrm{~mm}(80 \mathrm{mils})$ in diameter. The remaining clasts are sands and silts, with sand composing $\approx 35$ to $45 \%$ of the sediment volume, and mud the final 5 to $15 \%$. The minerals that make up these sediments are relatively slow to react and include basalts, felsic rocks and quartz. These sediments are composed of up to $5 \%$ caliche (calcium carbonate) as estimated by a field geologist. The caliche is a secondary mineral precipitated from soll solution as it evaporates, and not deposited with the original sediments.

From the bottom of the muddy sandy gravel to the bottom of the borehole was a fine grained sand. The sand contained a small percentage of mud, estimated to be greater than $10 \%$ of the entire sediment package, but less than 25\%. In some cases, a small gravel fraction of up to $10 \%$ was aiso present in these sands. The sand is composed primarily of quartz, with some basalt clasts present, $10 \%$ or less. 


\section{A2.2 MOYSTURE CONTENT}

Sediment moisture content samples were taken and analyzed according to the water content procedure (SA-7) defined in Procedures for Groundwater Investigations (PNL-MA-567). The sediment molsture content was generally low, which is characteristic of sediments from the Hanford site. Typically, the moisture content of sediments decreases with depth, as indicated in Table A-2, Figures $A-2$ and $A-3$. The moisture content of sediments near the surface is most likely to be influenced by the weather conditions of the season during which the measurements were made. The drilling of these holes took place in July, probably the hottest and driest time of the year. Consequently, the evaporation potential is likely to be highest at this time, and the sediment moisture content lowest.

Sediments encountered during drilling include fine grained loess, sand, and gravels. The most fine grained sediments encountered were those closest to the ground surface: the loess (muddy sand) from 0 to $1 \mathrm{~m}(0$ to $4 \mathrm{ft}$ ) depth. Unfortunately, moisture content samples were not collected from these sediments because cassettes were not installed at this depth. Sediments from 1 to $4 \mathrm{~m}$ ( 4 to $12 \mathrm{ft}$ ) depths contained the largest clasts. These sediments were found to have the highest molsture content of any measured. Below the gravelly sediments, from around the $3 \mathrm{~m}(10 \mathrm{ft})$ depth down to the bottom of the boreholes, the moisture contents generally decrease with increased depth.

\section{A2.3 SOIL GAS OXYGEN CONTENT}

Soil gas oxygen content measurements were taken using a Gastechtor 32520X probe, calibrated with gas canisters. This probe is accurate to a percentage point. Oxygen content was measured in October 1993, two months after the metal coupons were installed. Oxygen content is uniform with depth, all depths measured $21 \%$ of the gas present to be oxygen.

\section{A3.0 DATA INTERPRETATION}

Data included in this discussion include the sediment moisture content and the sediment 1ithology information collected in July of 1993 during the cassette installations, and the oxygen content of the soll gas collected in October 1993. The oxygen content of the soll gas was found to not vary with depth and the data collected will most likely reflect the recent exposure. of the sediments to the atmosphere. The sediment moisture content data collected showed a general decrease in moisture content with depth, with some variation.

1 Gastechtor is a trademark of the Gas Tech company. 


\section{A3.1 SEDIMENT MOISTURE CONTENT}

Sediment molsture content for any specific layer is influenced by the atmosphere, the blologic conditions, and by the adjacent sediments. The sediment properties such as the sediment size and mineralogy also play an important part in the amount of moisture retained and measured. The smaller the size of the sediments, the more likely the sediments are to retain moisture. Generally the higher mud content (silt and clay) sediments have a higher molsture content, in part due to the fact that there is a greater ratio of surface area to sediment volume as the sediment clasts increases (with the increase in surface area to volume ratio), sediment size becomes smailer. As the proportion of water in contact with the potential for moisture adsorption to sediment surfaces increases, causing the moisture to remain in place for longer. In addition, the smalier the sediment size is, the smaller the pore spaces are between sediment clasts. Water moves more slowly through smaller pore spaces because of the smaller volume available.

The amount of moisture avallable for infiltration through the sediments, the rate at which it migrates downward, and the rate at which it evaporates influence the amount of moisture that is present and then measured as moisture content. The low sediment moisture contents found during this project occurred because evaporation potential of the atmosphere greatly exceeds the precipitation rate (Gee et al. 1989). Most precipitation in July evaporates at or near the ground surface before infiltrating more than a few centimeters (Rockhold et al. 1990). As a consequence, sediments in the shallow surface, and closest to the atmosphere, are likely to lose moisture most rapidly from the evaporation and transpiration processes. Moisture is thereby transferred from the shallow subsurface to the atmosphere.

The relatively higher moisture contents measured at the $1.5 \mathrm{~m}(5 \mathrm{ft})$ depth suggest that more moisture is being retained by sediments at this depth. Evaporation is no longer the dominant process influencing water movement. The fact that the sediment sizes are larger here is not as significant as the fact that the rate of moisture transport to the atmosphere by evaporative flux is significantly reduced compared with more shallow subsurface evaporation rates (at less than $0.1 \mathrm{~m}[0.3 \mathrm{ft}]$ depth).

The subsurface moisture contents observed are likely to have been influenced also by the fact that this area received more precipitation in the spring of 1993 than normal. The greater amount of precipitation probably caused an increase in the amount of molsture that infiltrated into the subsurface. Moisture infiltrated progressively downward through the shallow silty sands into the underlying gravelly sediments. Not, however, as far as the lowermost sands, whose moisture content was found to be generally less than the gravels above. Over the course of the study it is iikely that the moisture will continue to infiltrate downward. The moisture content in the coarse sediments is likely to decrease with downward migration, and that of the underlying sands, into which the moisture will move to increase. 
WHC-EP-0769

\section{A2.3 SOIL GAS OXYGEN CONTENT}

The uniform oxygen content measured in october is unlikely to reflect the subsurface gas content before the facility installation. Wood (1991) measured oxygen concentration in the subsurface of loess sediments in Eastern Washington to a depth of $4.3 \mathrm{~m}(14 \mathrm{ft})$ and found that oxygen content decreased with depth, depending upon the season. During the spring and summer months, to a depth of $\approx 2 \mathrm{~m}(\approx 6.5 \mathrm{ft})$, there was a spike in the oxygen content. The data collected over a 1.5 year period shows both a negative and a positive spike in oxygen content in the shallow subsurface (1ess than $2 \mathrm{~m}[6.5 \mathrm{ft}]$ down). The oxygen content decreases to a concentration of $14 \%$ and increases to $22 \%$ during the warmer months in the sediments within $3 \mathrm{~m}(10 \mathrm{ft})$ of the surface. Below the $3 \mathrm{~m}(10 \mathrm{ft})$ depth the oxygen concentration shows a consistent decreasing trend with depth, with values that range between $20 \%$ and $16 \%$.

Oxygen content of the soll gas is also likely to change as a function of barometric pressure. Soil gas is in contact with gases in the atmosphere, and the changes in atmospheric gas pressure induce a pumping effect on the gases in the subsurface (Weeks 1978). The pressure difference between the gases at the surface and those in the subsurface creates a pressure gradient that transfers atmospheric gases to and from the subsurface. The oxygen content of the sediments, therefore, is likely to vary with the changes in the barometric pressure.

Most subsurface communication with surface moisture and gases is 1 imited to the sediments that are within 3 meters of the ground surface. As stated previously, the data collected by Wood on subsurface $\mathrm{O}_{2}$ and $\mathrm{CO}_{2}$ concentrations show that the most significant variations in subsurface gas content occur in the uppermost $3 \mathrm{~m}(10 \mathrm{ft})$. This indicates that the majority of atmospheric gas transfer to the subsurface by the pressure differentlal occurs within the uppermost $3 \mathrm{~m}(10 \mathrm{ft})$ of the sediments. In addition, the extent of moisture infiltration before evaporation or transpiration is about the same depth, $2 \mathrm{~m}$ $(6.5 \mathrm{ft}$ ) (Gee et al. 1989). The decreasing trend in oxygen concentration observed below that depth by Wood (1991) is likely caused by accumulation of the effects of microbial aerobic respiration. Aerobic respiration consumes oxygen and produces carbon dioxide as a byproduct. The decreased rate of gas transport to the atmosphere below the $3 \mathrm{~m}(10 \mathrm{ft})$ depth effectively traps $\mathrm{CO}_{2}$ produced by respiration, and preserves the decreased $\mathrm{O}_{2}$ concentration observed by Wood below the $3 \mathrm{~m}(10 \mathrm{ft})$ depth.

The subsurface sediments at the Hanford Site are likely to display a similar trend in oxygen concentration with depth as those found near Puliman, Washington by Wood. However, there are some notable differences in the environments. There is less moisture present in the subsurface at the Hanford Site that would be available to transfer nutrients to microorganisms. In addition, the lower soil moisture contents would open a greater volume of the soil voids to gas transport, effectively increasing the gas permeability of the sediments. The lower moisture content of the sediment and consequent decreased accessibility of nutrients to microorganisms probably decreases the respiration rate. 
The processes of metal corrosion and microbial respiration, likely to consume subsurface oxygen, probably occur at a slow rate. It appears that effects of these processes did not alter the subsurface gas content sufficiently to be detected after the two month period elapsed between cassette emplacement and measurement collection. In addition, another factor may contribute to uniform oxygen content measured: the higher sediment size below the $1 \mathrm{~m}(3.2 \mathrm{ft})$ depth may allow greater communication of the subsurface gases with the atmosphere, and cause the oxygen depleted by these processes to be replaced relatively rapidly.

The effects of those processes influencing subsurface oxygen content cannot be adequately interpreted from the single data point collected so far. oxygen content is likely to vary with the changes in the barometric pressure, the microbial respiration rate, as well as the chemical reactions of the sediments with the metal coupons emplaced during this project. The results of the continued monitoring of the subsurface oxygen content will provide information with which to interpret the process rates and their influence on the subsurface gas content present.

\section{A4.0 FUTURE WORK}

Work that will be done in the future includes completion of the installation of the field facility, and the monitoring of subsurface conditions on a periodic basis. In addition, the cassettes will be excavated at the 6 month, 1 year, 2 year, 4 year, 8 year, and 16 year intervals. Finally, the subsurface cassettes to be excavated at the 6 month period must be replaced with another set buried for the 16 year study.

Subsurface gas content and sediment moisture content measurements will be required on an annual basis. Continuing oxygen content measurements will be done on an annual basis.

It is recommended that $\mathrm{CO}_{2}$ content be measured at the same time as $\mathrm{O}_{2}$ content for evaluation of the influence of microbiologic respiration on oxygen concentrations measured. Carbon dioxide can be measured with the same probe used for oxygen measurement, and will not add significantly to the time allotted for collection of oxygen content measurements. The data collected will allow a more thorough evaluation of the subsurface processes that contribute to oxygen consumption and metal coupon corrosion.

Sediment moisture content measurements will be taken with a neutron probe. This probe will be calibrated with the previously collected measurements, using a field calibration facility and a standard calibration procedure. This operation is currently being carried out. 


\section{A5.0 REFERENCES}

Folk, R. L., 1968, Petrology of Sedimentary Rocks, University of Texas Press, Austin, Texas.

Gee, G. W., M. L. Rockhold, and J. L. Downs, 1989, Status of FY 1988 SoilWater Balance Studies on the Hanford Site, Prepared for the U.S. DOE under Contract DE-AC06-76RLO 1830, PNL-6750, Pacific Northwest Laboratory, Richland, Washington.

PNL, 1988 et seq., frocedures for Groundwater Investigations, PNL-MA-567, Pacific Northwest Laboratory, Richland, Washington.

Rockhold, M. L., M. J. Fayer; G. W. Gee, and M. J. Kanyid, 1990, Natural Groundwater Recharge and Water Balance at the Hanford Site, Prepared for the U.S. DOE under Contract DE-AC06-76RLO 1830, PNL-7215, Pacific Northwest Laboratory, Richland, Washington.

Weeks, E. P., 1978, "Field Determination of Vertical Permeability to Air in the Unsaturated Zone," GPO Professional Paper 1051, p. 2.

Wood, B. D., 1991, "Carbon Dioxide as a Measure of Microbial Activity in the Unsaturated Zone," Washington State University, Pullman, Washington. 
Figure A-1. Cross Section of the Monitored Borehole, 699-49-71A, the Lithologies Encountered During Drilling, and the Depths at Which the Coupon Cassettes Were Installed.

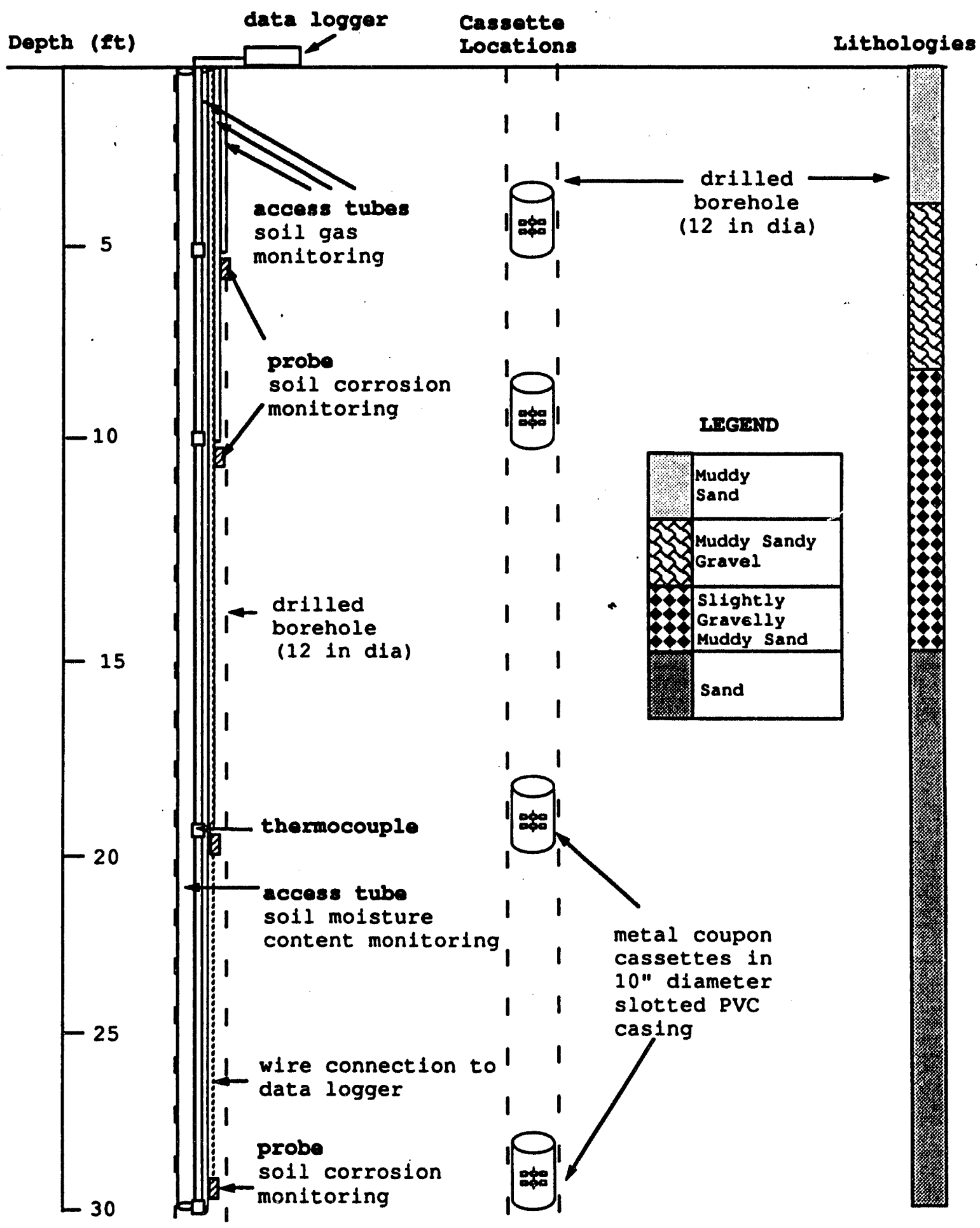


WHC-EP-0769

Figure A-2. Soil Moisture Content With Depth (a) 699-49-71A,

(b) 299-49-71B.

Well No. 699-49.71A

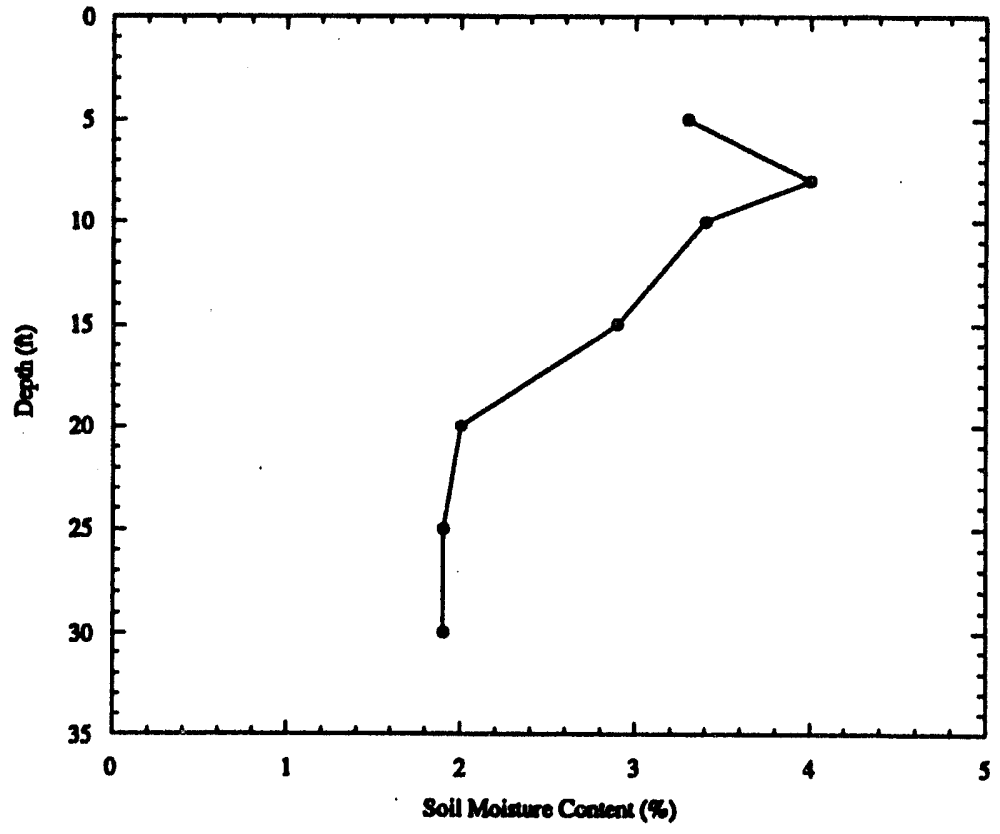

Well No. 699-49-71B -

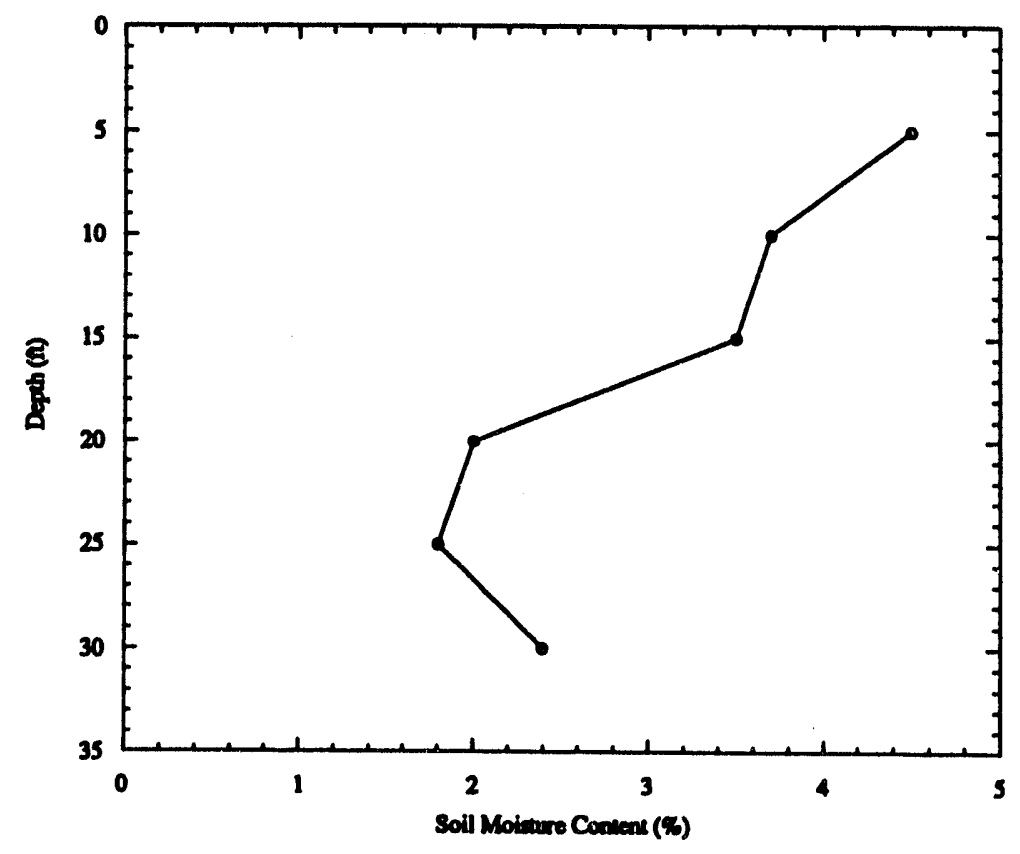




\section{WHC-EP-0769}

Figure A-3. Soil Moisture Content With Depth (a) 699-49-71C,

(b) 299-49-71E.

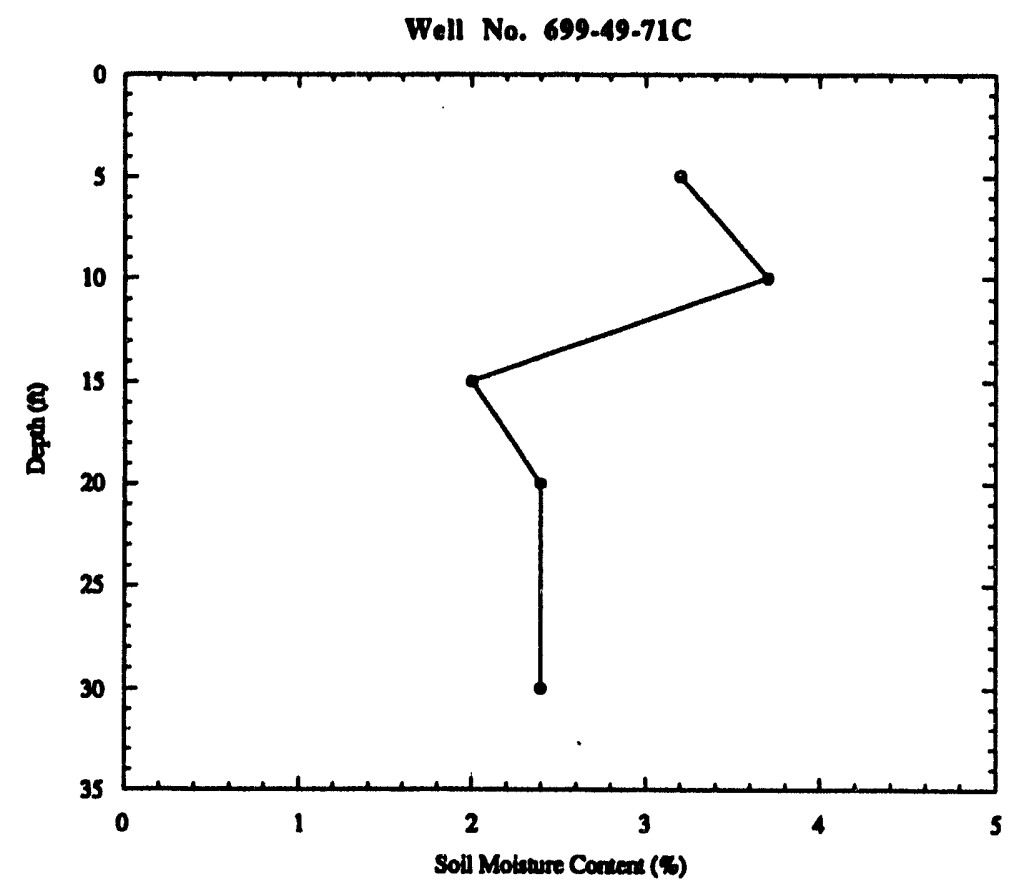

Well No. 699-49.71E

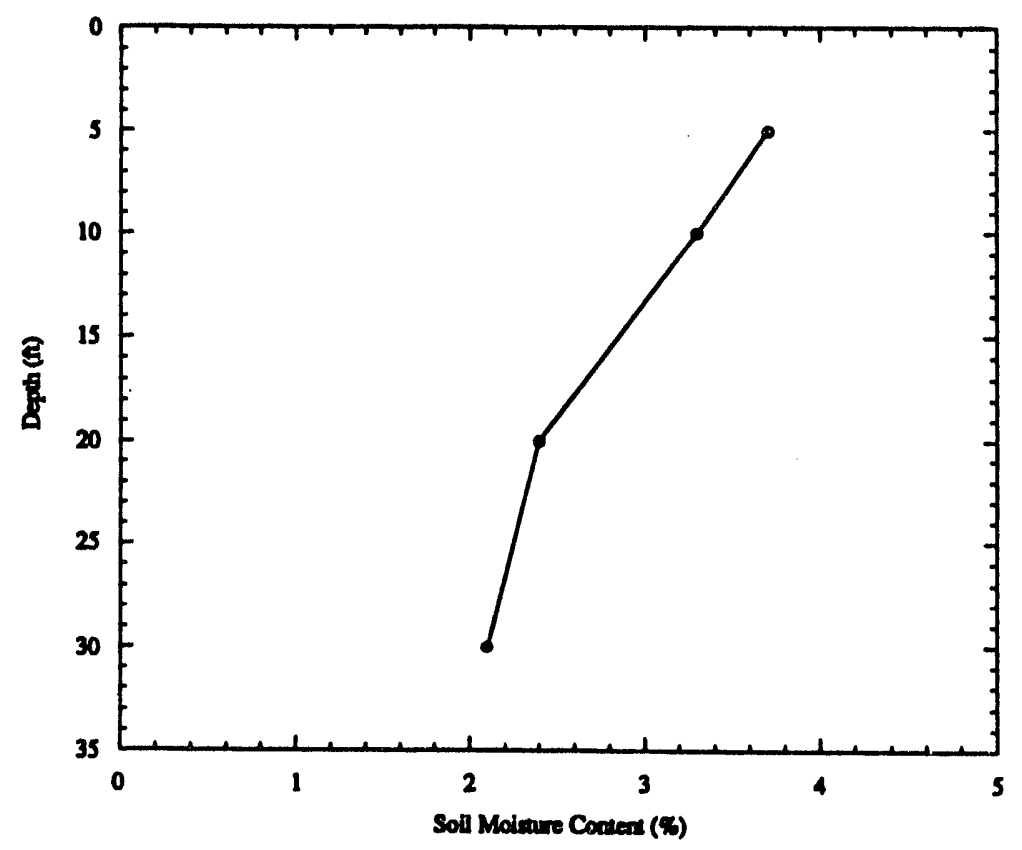


Table A-1. Cassette Number and Location with Depth and Borehole.

\begin{tabular}{|c|c|c|c|c|c|}
\hline \multirow{2}{*}{$\begin{array}{c}\text { Depth } \\
(\mathrm{ft})\end{array}$} & \multicolumn{5}{|c|}{ Well number 699-49-71B } \\
\cline { 2 - 6 } & $(\mathrm{B})$ & $(\mathrm{C})$ & $(\mathrm{D})$ & $(\mathrm{E})$ & $(\mathrm{F})$ \\
\hline 5 & $4^{*}$ & 6 & 1 & $9^{*}$ & 11 \\
\hline 10 & $3^{*}$ & 8 & 2 & 13 & 16 \\
\hline 20 & $5^{*}$ & 25 & 7 & 18 & 17 \\
\hline 30 & $7^{*}$ & 10 & 12 & 19 & 23 \\
\hline
\end{tabular}

"Indicates cassette number uncertain, see text in Section 1.2.

Table A-2. Sediment Moisture Content and Soil Gas Oxygen Content.

\begin{tabular}{|c|c|c|c|c|c|}
\hline \multirow{3}{*}{$\begin{array}{c}\text { Depth } \\
(\mathrm{ft})\end{array}$} & \multicolumn{5}{|c|}{ We11 number 699-49-71A } \\
\cline { 2 - 6 } & \multicolumn{5}{|c|}{$\begin{array}{c}\text { Moisture content } \\
\text { (\% by weight) }\end{array}$} \\
\cline { 2 - 6 } & $(\mathrm{A})$ & $(\mathrm{B})$ & $(\mathrm{C})$ & $(\mathrm{E})$ & $(\mathrm{A})$ \\
\hline 5 & 3.3 & 4.5 & 3.2 & $3.7^{*}$ & 21 \\
\hline 8 & 4.0 & -- & -- & -- & -- \\
\hline 10 & 3.4 & 3.7 & 3.7 & $3.3^{*}$ & 21 \\
\hline 15 & 2.9 & 3.5 & 2.0 & -- & -- \\
\hline $20^{\circ}$ & 2.0 & 2.0 & 2.4 & 2.4 & 21 \\
\hline 25 & 1.9 & 1.8 & -- & -- & -- \\
\hline 30 & 1.9 & 2.4 & 2.4 & 2.1 & 21 \\
\hline
\end{tabular}

"At time of analysis the outside surface of the sample container was moist and rusted. 
WHC-EP-0769

\section{APPENDIX B}

GROUND-PENETRATING RADAR SURVEY

B-1 
WHC-EP-0769

This page intentionally left blank. 


\section{GROUND-PENETRATING RADAR SURVEY}

On June 11, 1993, four ground-penetrating radar (GPR) surveys were completed of the Container Corrosion Study test site. To perform these surveys, a $15 \mathrm{~m} \times 15 \mathrm{~m}$ (50 ft $\times 50 \mathrm{ft}$ ) grid was marked using spray paint. The corners of this grid are now marked with stakes. The grid is centered within the stakes and is oriented approximately $\mathrm{N}-\mathrm{S}$ and $\mathrm{E}-\mathrm{W}$. References to coordinates in the following text are based on an origin at the SW corner of the grid.

Two antennas were used. These had center frequencles at $120 \mathrm{MHz}$ and $500 \mathrm{MHz}$. The low-frequency antenna provided maximum penetration. The high-frequency antenna provided less penetration, but better spatial resolution. With each antenna, data was collected along both the N-S and $E-W$ grid 1 ines. The line spacing was $0.75 \mathrm{~m}(2.5 \mathrm{ft})$.

The main result of the data analysis found no evidence of any buried pipelines, cables, tanks, other manmade objects. However, there are some apparently naturai features of note.

- There is an apparent sedimentary interface at a depth of $\approx 2$ to $2.5 \mathrm{~m}$ $(\approx 6$ to $8 \mathrm{ft}$ ). This interface strongly reflected the GPR signals, thereby limiting the effective penetration depth, although the recorded data contain some information to a depth of $\approx 4 \mathrm{~m}(\approx 14 \mathrm{ft})$. Additional data could be obtained from below this interface with another survey and a modified approach. This interface appears uneven with a general slope toward the south; however, the undulations may be a result of variation's in the electrical properties of the overlying soil layer.

- The layer below the interface might be rocky. The GPR profiles show strong reflections at the interface that are characteristic of localized reflectors such as cobbles.

- There is a strong near-surface reflection $(\approx 0.6 \mathrm{~m}[\approx 2 \mathrm{ft}]$ deep) at coordinates $13 \mathrm{E}, 37.5 \mathrm{~N}$. This is the only significant anomaly in the layer above the interface.

- There is another notable anomaly, presumably rocks, at the depth of $\approx 3 \mathrm{~m}(\approx 9 \mathrm{ft})$ at coordinetes $0-13 \mathrm{E}, 35-38 \mathrm{~N}$. 
WHC-EP-0769

This page intentionally left blank.

B-4 
WHC-EP-0769

\section{DISTRIBUTION}

Number of Copies

ONSITE

19

West inghouse Hanford Company

D. L. Byron

H5-37

W. C. Carlos

D. R. Duncan (10)

K. L. Hladek

M. M. McCarthy

H5-67

H5-33

H5-33

N3-13

R. J. Roberts

K1-45

Central Files

Information Release

Administration (3)

L8-04

L8-07

5

Pacific Northwest Laboratory

L. R. Bunnell

P8-44

L. A. Doremus

K6-84

G. M. Holter

J. B. Topping

PNL Technical Files

K7-97

K6-84

$\mathrm{K} 1-11$

3

U.S. Department of Energy.

Richland Operations Office

R. M. Gordon

R3-80

R. F. Guercia

R3-80

DOE-RL Public Reading Room

$\mathrm{H} 2-53$ 
WHC-EP-0769

This page intentionally left blank.

Distr-2 

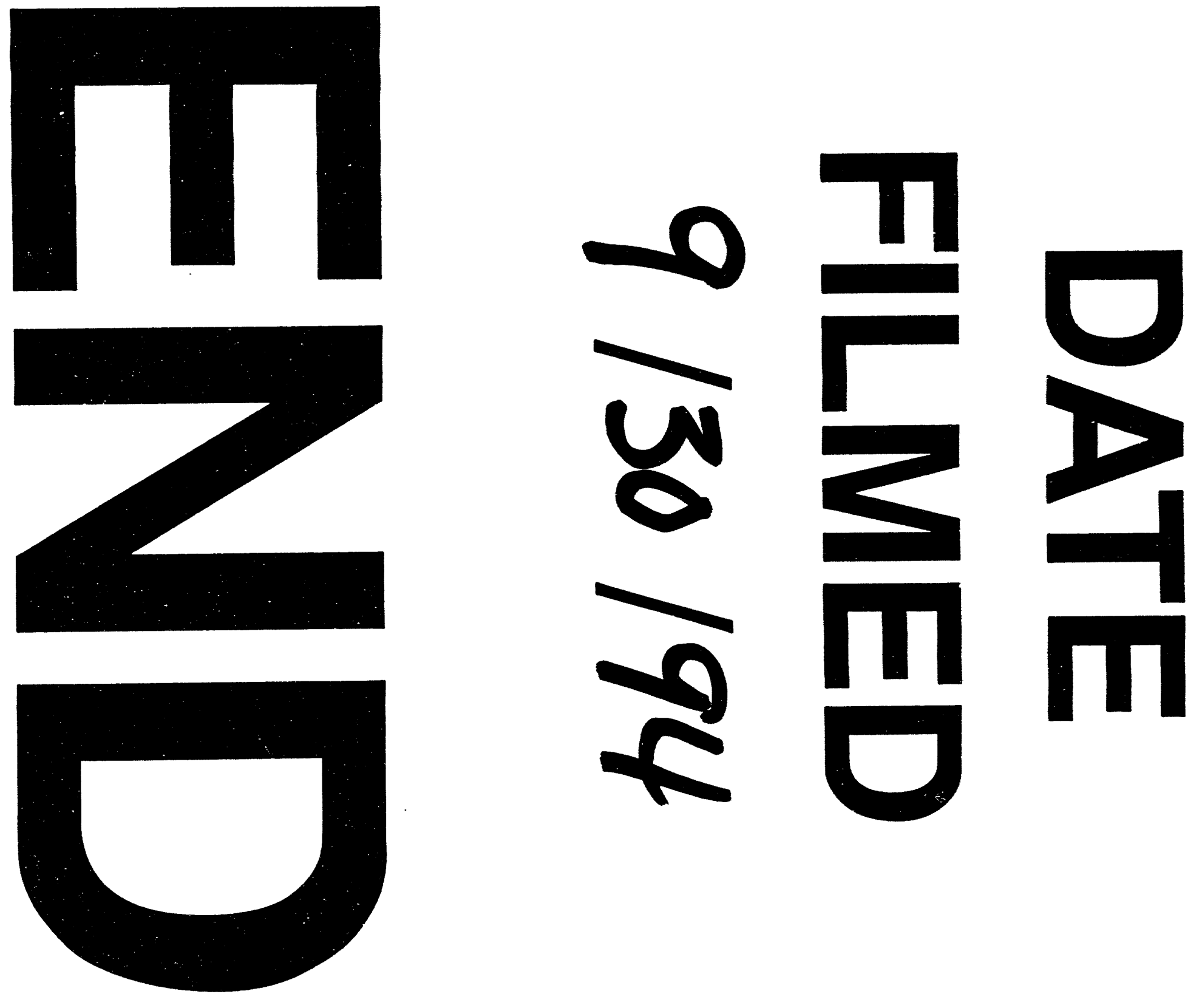
